University of South Florida

DIGITAL COMMONS

Digital Commons @ University of

@ UNIVERSITY OF SOUTH FLORIDA

South Florida

School of Geosciences Faculty and Staff

Publications

School of Geosciences

8-2015

\title{
Space Geodetic Observation of the Deformation Cycle across the Ballenas Transform, Gulf of California
}

\author{
Christina Plattner \\ University of Miami \\ Rocco Malservisi \\ University of South Florida, rocco@usf.edu \\ Falk Amelung \\ University of Miami \\ Timothy H. Dixon \\ University of South Florida, thd@usf.edu \\ Matthias Hackl \\ Ludwig-Maximilians Universität München
}

See next page for additional authors

Follow this and additional works at: https://digitalcommons.usf.edu/geo_facpub

Part of the Earth Sciences Commons

\section{Scholar Commons Citation}

Plattner, Christina; Malservisi, Rocco; Amelung, Falk; Dixon, Timothy H.; Hackl, Matthias; Verdecchia, Alessandro; Lonsdale, Peter; Suarez-Vidal, Francisco; and Gonzalez-Garcia, Javier, "Space Geodetic Observation of the Deformation Cycle across the Ballenas Transform, Gulf of California" (2015). School of Geosciences Faculty and Staff Publications. 1531.

https://digitalcommons.usf.edu/geo_facpub/1531

This Article is brought to you for free and open access by the School of Geosciences at Digital Commons @ University of South Florida. It has been accepted for inclusion in School of Geosciences Faculty and Staff Publications by an authorized administrator of Digital Commons @ University of South Florida. For more information, please contact digitalcommons@usf.edu. 


\section{Authors}

Christina Plattner, Rocco Malservisi, Falk Amelung, Timothy H. Dixon, Matthias Hackl, Alessandro Verdecchia, Peter Lonsdale, Francisco Suarez-Vidal, and Javier Gonzalez-Garcia 


\section{Journal of Geophysical Research: Solid Earth}

\section{RESEARCH ARTICLE}

10.1002/2015JB011959

Key Points:

- Deformation from Ballenas Transform, Gulf of California, observed by Space Geodesy

- Geodetic data used in interseismic and coseismic dislocation modeling

- Model fault locations and orientation agree with the fault bathymetry mapping

Supporting Information:

- Tables S1 and S2

- Figure S1

- Figure S2

Correspondence to:

C. Plattner,

christina.plattner@Imu.de

\section{Citation:}

Plattner, C., R. Malservisi, F. Amelung

T. H. Dixon, M. Hackl, A. Verdecchia,

P. Lonsdale, F. Suarez-Vidal, and

J. Gonzalez-Garcia (2015), Space

geodetic observation of the deformation

cycle across the Ballenas Transform, Gulf

of California, J. Geophys. Res. Solid Earth,

120, 5843-5862, doi:10.1002/

$2015 J B 011959$.

Received 13 FEB 2015

Accepted 26 JUN 2015

Accepted article online 1 JUL 2015

Published online 12 AUG 2015

(C2015. American Geophysical Union. All Rights Reserved.

\section{Space geodetic observation of the deformation cycle across the Ballenas Transform, Gulf of California}

\author{
Christina Plattner ${ }^{1,2}$, Rocco Malservisi ${ }^{3}$, Falk Amelung ${ }^{2}$, Timothy H. Dixon ${ }^{3}$, Matthias Hackl', \\ Alessandro Verdecchia ${ }^{1}$, Peter Lonsdale ${ }^{4}$, Francisco Suarez-Vidal ${ }^{5}$, and Javier Gonzalez-Garcia ${ }^{5}$ \\ ${ }^{1}$ Ludwig-Maximilians Universität München, Munich, Germany, ${ }^{2}$ Rosenstiel School of Marine and Atmospheric Sciences, \\ University of Miami, Miami, Florida, USA, ${ }^{3}$ Department of Geology, University of South Florida, Tampa, Florida, USA, ${ }^{4}$ Scripps \\ Institution of Oceanography, University of California, San Diego, California, USA, ${ }^{5}$ Centro de Investigación Científica y de \\ Educación Superior de Ensenada, Ensenada, Mexico
}

\begin{abstract}
The Gulf of California, Mexico, accommodates $~ 90 \%$ of North America-Pacific plate relative motion. While most of this motion occurs on marine transform faults and spreading centers, several fault segments in the central Gulf come close to peninsular Baja California. Here we present Global Positioning System and interferometric synthetic aperture radar data near the Ballenas transform fault, separating the peninsula from Angel de la Guarda Island. We observe interseismic motion between June 2004 and May 2009 and displacements associated with the 3 August $2009 M_{w} 6.9$ earthquake. From the interseismic data we estimate a locking depth of 9-12.5 km and a slip rate of 44.9-48.1 mm/yr, indicating that faults east of Angel de la Guarda deform at negligible rates and that the Ballenas Transform accommodates virtually all of the relative motion between the North American plate and the Baja California microplate. Our preferred model for coseismic slip on a finite rectangular fault plane suggests $1.3 \mathrm{~m}$ of strike-slip displacement along a vertical rupture plane that is $60 \mathrm{~km}$ long and extends from the surface to a depth of $13 \mathrm{~km}$ in the eastern Ballenas Channel, striking parallel to Baja California-North America relative plate motion. These estimates agree with the seismic moment tensor and the location of the major foreshock and aftershocks and are compatible with the fault location identified from high-resolution bathymetric mapping. The geodetic moment is $33 \%$ higher than the seismic moment in part because some afterslip and viscous flow in the first month after the earthquake are included in the geodetic estimate. Coulomb stress changes for adjacent faults in the Gulf are consistent with the location of smaller aftershocks following the 2009 main shock and suggest potential triggering of the 12 April $2012 M_{w} 6.9$ Guaymas earthquake.
\end{abstract}

\section{Introduction}

The Gulf of California, Mexico, formed by separation of peninsular Baja California from North America between 12 and $6 \mathrm{Ma}$ [Atwater and Stock, 1988, 1998; Lonsdale, 1989]. Its transtensional fault system is composed of an en echelon array of long right-lateral transform fault segments that alternate with short extensional basins and spreading ridges (Figure 1). This tectonic setting provides a unique opportunity to study deformation associated with the transition of a continental strike-slip fault (the San Andreas Fault) to seafloor spreading (East Pacific Rise) along a rapidly moving fault system [Faulds et al., 2005a, 2005b; McQuarrie and Wernicke, 2005; Li and Liu, 2006; McCrory et al., 2009; Plattner et al., 2010]. About 90\% of the full North America-Pacific plate relative motion rate (approximately $43-47 \mathrm{~mm} / \mathrm{yr}$ ) is accommodated along the Gulf of California [DeMets et al., 1990, 1994; DeMets and Dixon, 1999; Dixon et al., 2000a; Plattner et al., 2007, 2009]. Because of the submarine setting, however, crustal deformation studies have largely been limited to the interpretation of faulting processes that occur over short time scales in the seismogenic zone [Munguia et al., 1977; Goff et al., 1987; Rebollar et al., 2001; Rodriguez-Lozoya et al., 2008; Castro et al., 2010, 2011; Sumy et al., 2013; Lopez-Pineda et al., 2014].

The Guaymas fault system [Lonsdale, 1989] consists of several right-stepping and branching strike-slip fault zones that link the northeast end of a Guaymas Basin spreading axis in the central Gulf to the southwest end of the Lower Delfin axis, about $355 \mathrm{~km}$ to the northwest in the northern Gulf (Figure 1). The Ballenas fault zone is the northernmost part of this fault system, and more than half of its $93 \mathrm{~km}$ length occupies the 10-20 km wide marine channel (Ballenas Channel) that separates Angel de la Guarda Island from the Baja California peninsula and along which the plate boundary segment is highly localized (Figure 2). An early attempt [Vacquier and Whiteman, 1973] to measure fault displacement across the narrowest part of 


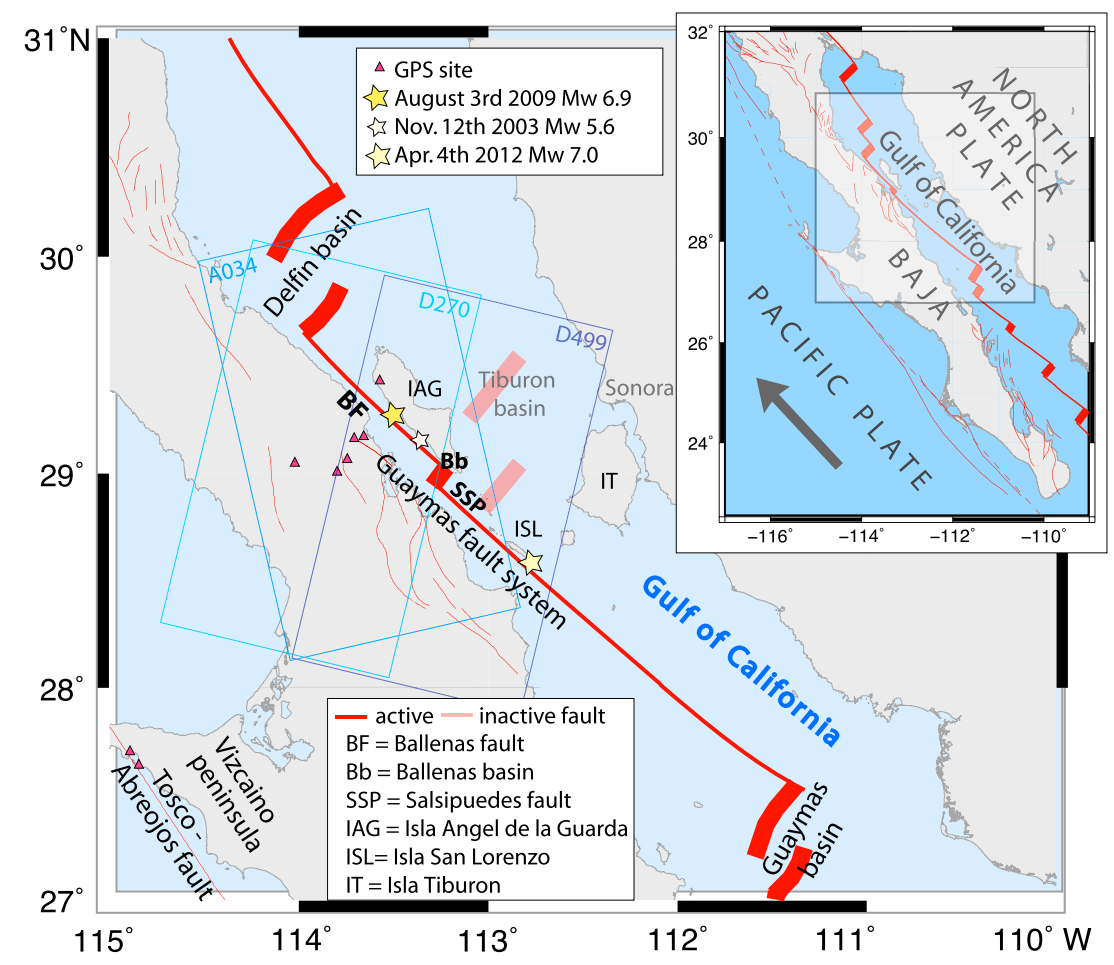

Figure 1. The Gulf of California transtensional fault system accommodates about $90 \%$ ( $43-47 \mathrm{~mm} / \mathrm{yr}$ ) of North AmericaPacific plate relative motion. The Ballenas transform fault is located within a 10-20 km narrow marine channel in between Baja California peninsula and Angel de la Guarda Island (IAG). Interferometric synthetic aperture radar data from Envisat satellite (track positions are shown as blue boxes) and GPS campaign measurements (pink triangles).

Ballenas Channel was unsuccessful because of the low resolution of the optical parallax technique they used and the short (2 year) duration of their experiment (profile location is shown Figure 3). In 2004 we installed a campaign GPS network across the Ballenas Fault to monitor the interseismic motions (Figure 1). A $M_{w} 6.9$ earthquake occurred along Ballenas Channel on 3 August 2009 [Castro et al., 2011], allowing us to also study the coseismic and postseismic deformation from this event. To increase the spatial resolution of the coseismic observation we also acquired synthetic aperture radar (SAR) data for interferometric analysis.

The Global Centroid Moment Tensor catalog [Dziewonski et al., 1981; Ekström et al., 2012] locates the main shock near the axis of Ballenas Channel and approximately midway along the transform fault zone (Figures 1 and 2). It defines the fault plane to be near-vertical $\left(87^{\circ}\right)$, with a $131^{\circ}$ strike. One foreshock and three $>M_{w} 5$ aftershocks occurred within $48 \mathrm{~h}$ in approximately strike-parallel direction. Several smaller aftershocks clustered within and south of Lower Delfin Basin. Based on the distribution of the foreshock and aftershocks and the focal depth of the $>M_{w} 5$ events, fault length was estimated at 43 to $100 \mathrm{~km}$ and the rupture depth between 10 and $13.7 \mathrm{~km}$. Slip on the plane was estimated at $1.3 \mathrm{~m}$ [Castro et al., 2011].

Here we present analyses of both the interseismic velocity field derived from GPS data and the coseismic and postseismic displacement fields derived from GPS and interferometric synthetic aperture radar (InSAR) data. The velocity and displacement fields are then interpreted using dislocation modeling to derive the fault kinematics during different periods of the earthquake cycle. We compare our geodetic earthquake deformation model to published results from seismic data analysis and to the location and orientation of the fault trace as identified from limited seismic reflection profiling and multibeam bathymetry swath data [Lonsdale and Kluesner, 2010].

\section{Regional Geology of the Ballenas Fault Zone}

As is typical of most transform faults that originate by oblique separation of continental plates (e.g., the central Atlantic margins [Francheteau and Le Pichon, 1972]), most transform fault zones in the Gulf of 


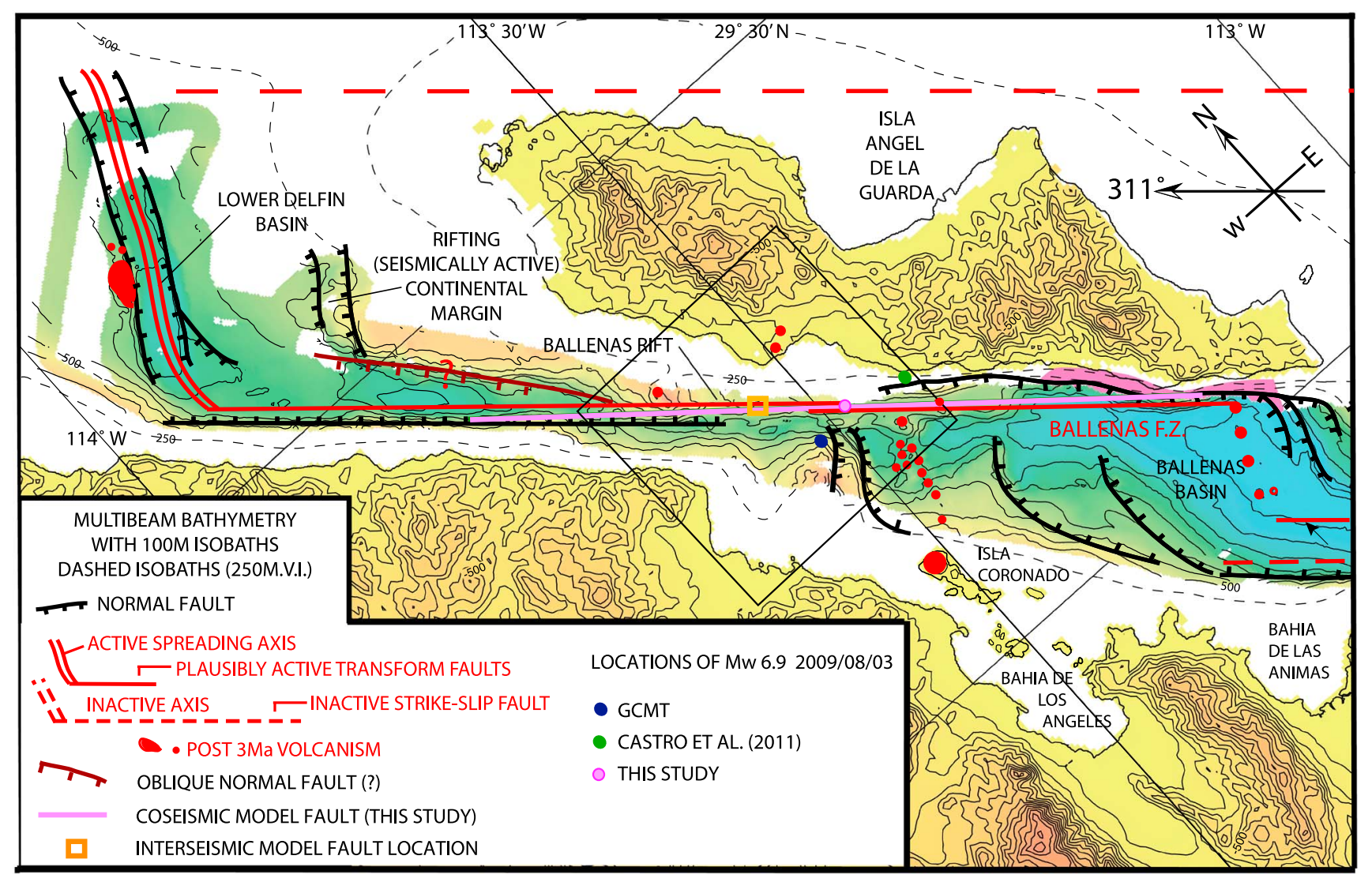

Figure 2. Multibeam bathymetry data and interpretation of fault zones. Fault segments between Lower Delfin Basin and Ballenas Basin. Map is oriented in oblique Mercator projection with the pole at Baja California-North America Euler pole [Plattner et al., 2007]. Coseismic model fault is shown in green; location and orientation of interseismic model fault is shown in orange. The black box shows outline of detailed map shown in Figure 3.

California originated as intracontinental strike-slip fault zones, then formed shearing continental margins separating continental lithosphere from newly accreted oceanic lithosphere, and are destined to become wholly oceanic transform fault zones in a widening strip of oceanic crust, as at the Tamayo fault zone in the southern Gulf. The Guaymas fault zone (Figure 1) occupies a shearing continental margin throughout most of its length in Guaymas Basin [Lonsdale, 1985], but the northern fault zones in this fault system are still almost entirely intracontinental because of the youth of the spreading centers they link. At the Ballenas Transform fault zone, specifically, the width of oceanic crust accreted to the North American plate at the Lower Delfin axis (which has an axial trough strongly resembling the pair in Guaymas Basin) is only $\sim 10 \mathrm{~km}$, and the width of crust accreted to the Baja California plate at the Ballenas axis, which is marked by a $10 \mathrm{~km}$ long row of tiny volcanic peaks from which Lonsdale sampled tholeiitic basalt in 2008, is probably even less. At its southwest end the Ballenas axis links to a fault zone in the floor of Salsipuedes Channel, separating Baja California from the San Lorenzo Island group (Figure 1). For $>80 \%$ of the length of both the Ballenas and the Salsipuedes fault zones the continental basement of Isla Angel de la Guarda and Isla San Lorenzo (Mesozoic granites and Cenozoic volcanics) is sliding past the similar continental basement of Baja California. The immaturity of the Lower Delfin and Ballenas Basins is further exemplified by active seismicity of their rifted continental margins, documented for the southeastern (Angel de la Guarda) margin of Lower Delfin Basin [Reichle and Reid, 1977] and for the northwestern (Baja California) margin of Ballenas Basin [Lopez-Pineda et al., 2014]; evidently, the "rifting-to-spreading transition" that is characteristic of the early growth of oceanic basins is still ongoing there.

The narrow width of oceanic crust that has accreted at the spreading axes intersected by the Ballenas Transform suggests that this transform may have formed in the past 2 Myr [Lonsdale, 1989]. However, spreading may have been preceded by a longer history of plate separation by detachment faulting, as has been proposed for other thickly sedimented basins in the northern Gulf [Martin-Barajas et al., 2013], and 


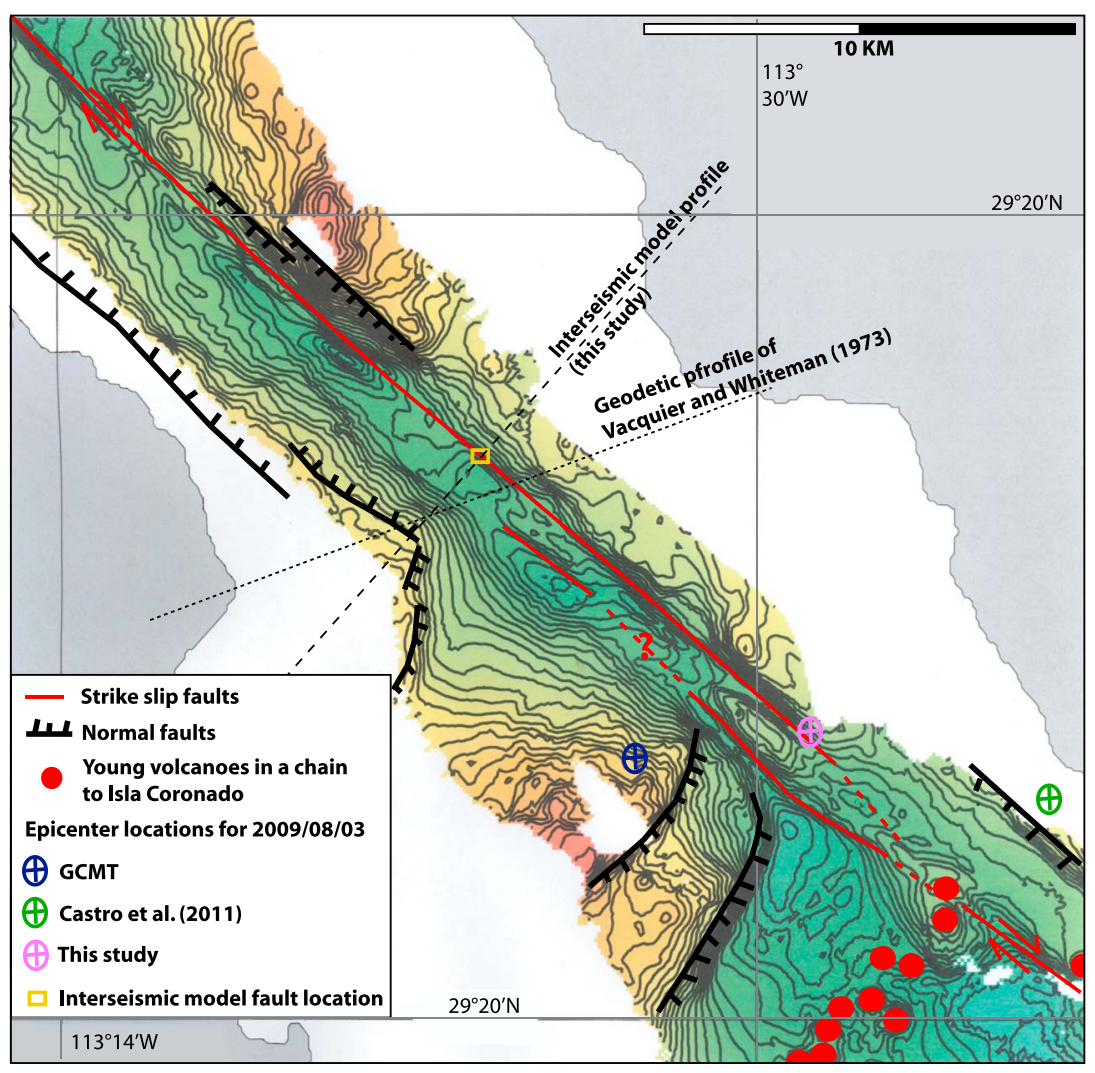

Figure 3. High-resolution bathymetry data and precise fault mapping from central Ballenas Channel, location of Ballenas fault zone shown as red lines.

the Lower Delfin axis is now overlapped by the less well defined Upper Delfin axis that may once have linked to the Ballenas fault zone. No tight constraints on total fault offset across this fault zone have been established by matching unique geologic "tie points" on Isla Angel de la Guarda and the peninsula. Stock et al. [2008] inferred from similarities between remnant patches of $12 \mathrm{Ma}$ ignimbrites on the island and others $130 \mathrm{~km}$ to the northwest in Baja California that these may be tie points that constrain the total slip on the fault to "a maximum of $130 \mathrm{~km}$," but ignimbrites of similar age and composition are widespread over a broad area of Baja California and the Sonora mainland. Escalona-Alcazar and Delgado-Argote [2000] suggested from structural and geologic similarities between Isla San Lorenzo and parts of the peninsula $50 \mathrm{~km}$ to the northwest on the other side of the Salsipuedes fault zone that the latter had accumulated about $50 \mathrm{~km}$ of right-lateral slip. It may have less fault offset than the Ballenas fault zone because some of the slip on the latter may have continued along the northeast side of the San Lorezo Islands to link up with the San Pedro Martir fault zone [Lonsdale, 1989], rather than stepping right across Ballenas Basin to the Salsipudes fault zone. It may do so still; several recent Global Centroid Moment Tensor (GCMT) locations (e.g., for a $M_{w} 6.9$ event 12 April 2012) plot to the northeast of the Salsipuedes fault zone, in alignment with Ballenas fault zone.

The Ballenas and Salsipuedes fault zones occupy deep structural rifts, with basement on seismic refection profiles at least $2 \mathrm{~km}$ below sea level along those parts near Ballenas and Lower Delfin Basins. These regions have a rapidly accumulating sediment fill of more than $1 \mathrm{~km}$, and there the seafloor trace of the fault zones on multibeam sonar imagery are subtle linear depressions, in places $2-4 \mathrm{~km}$ wide. Along shallower parts of the Ballenas rift, including a $50 \mathrm{~km}$ long middle section of the fault zone where the basement depth is less than $700 \mathrm{~m}$, fast bottom currents limit sediment accumulation, and the tectonic geomorphology is better displayed. Commonly these parts show with a narrow northwest striking $\left(311-312^{\circ}\right) 300-500 \mathrm{~m}$ wide slot that we interpret as the strike-slip fault trace across rocky seafloor. A short section, at longitude -113.5, near the location of the 3 August 2009 main event, has two slots with axes $1 \mathrm{~km}$ apart (Figure 2); we cannot tell if both are active traces. Near longitudes -113.63 and -113.75 there 
Table 1. Interseismic GPS Velocities With Respect to Stable Baja California Microplate ${ }^{\mathrm{a}}$ and Fault-Parallel Velocity Component ${ }^{\mathrm{b}}$

\begin{tabular}{|c|c|c|c|c|c|c|c|c|}
\hline GPS Site & $\begin{array}{l}\text { Longitude } \\
\qquad\left({ }^{\circ} \mathrm{E}\right)\end{array}$ & $\begin{array}{l}\text { Latitude } \\
\left({ }^{\circ} \mathrm{N}\right)\end{array}$ & $\begin{array}{l}\text { Velocity East } \\
\qquad(\mathrm{mm} / \mathrm{yr})\end{array}$ & $\begin{array}{c}\sigma \text { Velocity } \\
\text { East (mm/yr) }\end{array}$ & $\begin{array}{l}\text { Velocity North } \\
(\mathrm{mm} / \mathrm{yr})\end{array}$ & $\begin{array}{c}\sigma \text { Velocity } \\
\text { North }(\mathrm{mm} / \mathrm{yr})\end{array}$ & $\begin{array}{l}\text { Velocity Projected } \\
(\mathrm{mm} / \mathrm{yr})\end{array}$ & $\begin{array}{c}\sigma \text { Velocity Projected } \\
(\mathrm{mm} / \mathrm{yr})\end{array}$ \\
\hline BGUA & -113.66 & 29.21 & 7.2 & 1.1 & -5.1 & 0.9 & -8.7 & 1.0 \\
\hline BTAP & -114.92 & 27.72 & -1.3 & 2.1 & 2.5 & 1.5 & 2.6 & 1.8 \\
\hline HER2 & -110.97 & 29.09 & 33.4 & 0.5 & -27.7 & 0.5 & -43.2 & 0.5 \\
\hline IAG1 & -113.57 & 29.48 & 27.2 & 1.7 & -23.2 & 1.5 & -35.7 & 1.6 \\
\hline LSEC & -113.81 & 29.04 & 0.1 & 1.5 & 2.3 & 1.8 & -1.7 & 1.4 \\
\hline PCLY & -114.85 & 27.62 & -2.6 & 2.3 & 1.1 & 1.8 & 2.7 & 2.1 \\
\hline VIEJ & -114.04 & 29.08 & 0.2 & 1.4 & 0.0 & 1.2 & -0.1 & 1.3 \\
\hline VLSE & -113.75 & 29.10 & 3.0 & 1.4 & -3.6 & 1.0 & -4.7 & 1.2 \\
\hline YUBA & -113.72 & 29.20 & 5.2 & 1.5 & -3.9 & 1.2 & -6.4 & 1.4 \\
\hline
\end{tabular}

${ }^{\mathrm{a}}$ Euler vector describing the angular velocity of Baja California relative to ITRF08.

Longitude $108.59^{\circ} \mathrm{E}$, latitude $-63.74^{\circ} \mathrm{N}$; omega $0.6408 \pm 0.0182^{\circ} \mathrm{Myr}^{-1} ; \sigma_{\max }{ }^{\mathrm{C}} 1.6^{\circ}, \sigma_{\min }{ }^{\mathrm{c}} 0.2^{\circ} ;$ and azimuth ${ }^{\mathrm{d}}-57.5^{\circ}$.

In Cartesian coordinates where $x, y$, and $z$ are parallel to $\left(0^{\circ} \mathrm{N}, 0^{\circ} \mathrm{E}\right),\left(0^{\circ} \mathrm{N}, 90^{\circ} \mathrm{E}\right)$, and $\left(90^{\circ} \mathrm{N}\right)$, with omega in $10^{-3} \mathrm{rad} \mathrm{Myr}^{-1}$ : omega $x-1.5777521$, omega $y$ 4.6906174, and omega $z-10.0296245$.

Covariance matrix $\left(10^{-6} \mathrm{rad} \mathrm{Myr}^{-1}\right) x x=0.0267256, x y=0.0569943, x z=-0.0330101, y x=0.0569943, y y=0.1318893, y z=-0.0753641, z x=-0.0330101$,

$z y=-0.0753641, z z=0.0442525$.

${ }^{b}$ Velocity projected in direction of Ballenas Fault, azimuth $=314^{\circ}$ clockwise from north. Velocity uncertainties are projected as in Plattner et al. [2013].

${ }^{C}$ Length in degrees of the semimajor axis $\sigma_{\max }$ and semiminor axis $\sigma_{\min }$ of the $1 \sigma$ pole error ellipse. Both axes are derived from a 2-D error distribution.

dAzimuth of semimajor ellipse axis in degrees clockwise from north.

is evidence for short $(\sim 1 \mathrm{~km})$ right steps of the fault trace. The only fine-scale evidence of fault offset that we recognize is the possible $4-5 \mathrm{~km}$ right offset of a small, young (but undated) submarine volcano from a north striking chain of similar volcanoes that extends across the Ballenas Channel floor and the fault zone from the recently active, still fumarolic, volcano on Isla Coronado (Figure 2 ).

\section{Surface Deformation Data}

\subsection{GPS Data}

The GPS campaign network consists of six stations (Figure 1) that were installed and maintained by University of Miami (USA), University of South Florida (USA), Ludwig-Maximilians University of Munich (Germany), and Centro de Investigacion Cientifica y Education Superior de Ensenada (Mexico). Five of the sites are located within peninsular Baja California, along a transect passing through Bahia Los Angeles, and one site is located on the northwestern coast of Angel de la Guarda Island (IAG1). The stations were observed 2-3 times during the interseismic period between June 2004, October 2007, and May 2009, and again following the earthquake in September and December 2009 (station BGUA was occupied in late August 2009), and in May 2012. In addition to the local network, we processed data from three GPS stations to constrain the far-field velocities during the interseismic period. Two of these GPS stations are located in western Baja California at the Vizcaino peninsula (BTAP and PCLY, both campaign stations that were observed in 2007 and May 2009); the third is a continuous station in mainland Mexico (HER2 from Mexican National Geodetic Network RGNA-INEGI). We also reprocessed data from 10 sites within the rigid Baja California microplate that were used by Plattner et al. [2007] to derive a local reference frame.

The GPS data were processed at University of South Florida using GIPSY/OASIS II, Release 6.2 software and nonfiducial satellite orbit and clock files provided by the Jet Propulsion Laboratory [Zumberge et al., 1997]. The analysis generally followed Malservisi et al. [2015], with the daily solutions that were aligned to IGb08 [Rebischung et al., 2012].

The daily position data and uncertainties from 2004 to May 2009 are used in a weighted linear least squares regression to calculate the GPS horizontal and vertical velocities during the interseismic period (Table S1 in the supporting information). Outliers are defined as having a deviation from the linear trend that is 3 times the formal error. To estimate velocity uncertainties we use Mao et al. [1999]. For analysis of the interseismic velocity field we use the local reference frame that describes the rotation of the stable Baja California microplate (Table 1). The local reference frame was computed through the calculation of the Euler vector described by Plattner et al. [2007] using the 10 sites within stable Baja California with the addition of the site VIEJ to better constrain motion in the center of the peninsula. As shown in Figure 4 site VIEJ does not show significant deformation. The velocity field is shown in Figure 4 and discussed in section 4. 


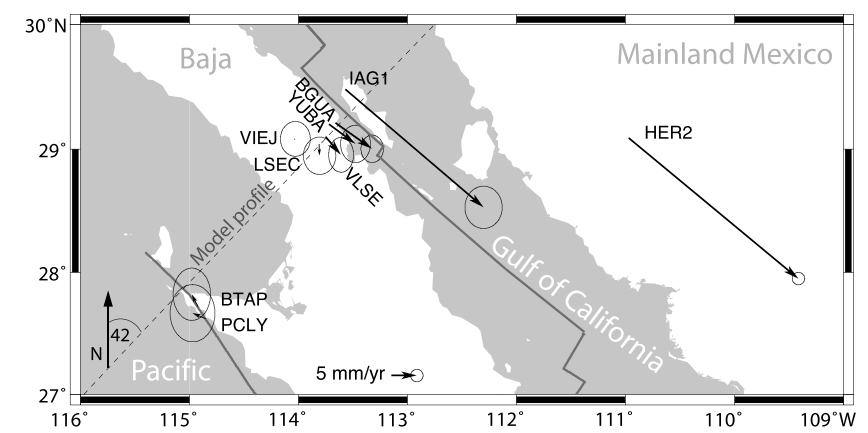

Figure 4. Interseismic velocity field from central Baja California campaign GPS network stations and permanent station HER2 on mainland Mexico shown in stable Baja California reference frame. GPS error ellipses correspond to $95 \%$ confidence. Model profile across the Ballenas is shown as thin dashed line.
To derive displacements during the coseismic and early postseismic periods (we refer to the early postseismic period as the time interval between the earthquake and the first geodetic measurement), we use the observations made in May and September 2009. First, we calculate the horizontal and vertical velocities for the time interval between the two measurements, then estimate the mean position for both campaign dates, and finally derive the position offset (Table 2). The displacement field is shown in Figure 5 and discussed in section 5 . The displacement uncertainties $\sigma_{\text {disp }}$ for each component (east, north, and up) are calculated as

$$
\sigma_{\text {disp }}=\sqrt{\left(\frac{\sum_{i=1}^{i=p} \sigma_{i}}{p}\right)^{2}+\left(\frac{\sum_{i=p+1}^{i=a} \sigma_{i}}{a-p}\right)^{2}}
$$

with $\sigma_{i}$ being the uncertainty of the estimated position for each single day, $p$ the number of measurements prior to the earthquake, and $a$ the number of measurements after the earthquake. We do not correct the data for interseismic strain accumulation between May and September 2009 because the bias is small, assuming an interseismic fault slip rate of $\sim 43-47 \mathrm{~mm} / \mathrm{yr}$ and a coseismic fault slip on the order of $1.3 \mathrm{~m}$.

Postseismic relaxation is calculated by fitting an exponential decay function to the position data from August (only available for BGUA), September, and December 2009. We avoid observations made in May 2012 because the preceding 12 April $2012 M_{w} 6.9$ earthquake at the Salsipuedes Fault has affected the position of stations in our network (Figure 6). We discuss the postseismic signal in section 6.

\subsection{InSAR Data}

We processed differential radar interferometry data spanning the earthquake main shock, foreshock, and aftershock period (3-5 August 2009), using Envisat satellite images from one ascending (A034) and two descending tracks (D270 and D499) (Figure 1). Whereas there are sufficient data from the descending tracks of 2009 and 2010 to obtain interferograms with small orbital baseline, there are few images from the ascending track prior to the earthquake. Therefore, we processed all data from 2003 onward. The processing was carried out at University of Miami using a modified version of Jet Propulsion Laboratory software ROI_PAC [Rosen et al., 2004], in which the single look-complex files were generated using GAMMA software. Topographic effects are corrected by application of a Shuttle Radar Topography

Table 2. GPS Displacements From May to September 2009 and Uncertainties

\begin{tabular}{|c|c|c|c|c|c|c|c|c|c|c|}
\hline GPS Site & $\begin{array}{l}\text { Longitude } \\
\left({ }^{\circ} \mathrm{E}\right)\end{array}$ & $\begin{array}{l}\text { Latitude } \\
\left({ }^{\circ} \mathrm{N}\right)\end{array}$ & $\begin{array}{l}\text { Displacement } \\
\text { East }(\mathrm{m})\end{array}$ & $\begin{array}{c}\sigma \text { Displacement } \\
\text { East }(\mathrm{mm})\end{array}$ & $\begin{array}{l}\text { Displacement } \\
\text { North }(\mathrm{m})\end{array}$ & $\begin{array}{c}\sigma \text { Displacement } \\
\text { North }(\mathrm{mm})\end{array}$ & $\begin{array}{c}\text { Displacement } \\
\text { Up (m) }\end{array}$ & $\begin{array}{c}\sigma \text { Displacement } \\
\text { Up }(\mathrm{mm})\end{array}$ & $\begin{array}{l}\text { Displacement } \\
\text { D-LOS }(\mathrm{m})\end{array}$ & $\begin{array}{c}\text { Displacement } \\
\text { A-LOS (m) }\end{array}$ \\
\hline BGUA & -113.66 & 29.21 & -0.2304 & 1.3 & 0.1203 & 1.7 & 0.0474 & 3.0 & -0.0261 & 0.1185 \\
\hline IAG1 & -113.57 & 29.48 & 0.0683 & 1.5 & -0.1820 & 2.2 & 0.0144 & 11.1 & 0.0223 & 0.0033 \\
\hline LSEC & -113.81 & 29.04 & -0.0649 & 2.5 & 0.02884 & 1.9 & 0.0003 & 6.3 & -0.0207 & 0.0205 \\
\hline VIEJ & -114.04 & 29.08 & -0.0609 & 2.0 & 0.0070 & 1.6 & 0.0058 & 5.1 & -0.0176 & 0.0246 \\
\hline VLSE & -113.75 & 29.10 & -0.0975 & 0.7 & 0.0446 & 0.9 & -0.0028 & 6.5 & -0.0337 & 0.0284 \\
\hline YUBA & -113.72 & 29.20 & -0.1782 & 1.9 & 0.0612 & 2.5 & 0.0109 & 11.0 & -0.0482 & 0.0712 \\
\hline
\end{tabular}

${ }^{\mathrm{a}}$ Displacement D-LOS is line of sight component of GPS data calculated for descending pass, and A-LOS is for ascending pass. 


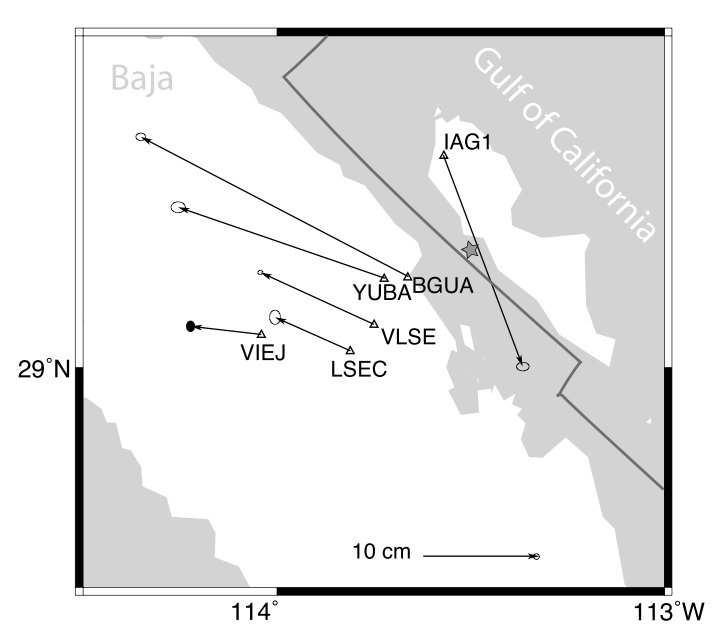

Figure 5. GPS displacement field derived from position measurements in May and September 2009. Earthquake epicenter is shown as grey star.
Mission digital elevation model with a resolution of $90 \mathrm{~m}$ [Farr and Kobrick, 2000]. Unwrapping of the interferograms is based on the Snaphu algorithm [Chen and Zebker, 2001].

We use the coseismic GPS displacements in Baja California to place the relative InSAR measurements into the GPS reference frame and to account for phase-unwrapping ambiguities at Angel de la Guarda Island. At Angel de la Guarda Island the calibration offset corresponds directly to the misfit of GPS site IAG1, while on the peninsula we calibrate with an offset that minimizes the average misfit between all GPS sites within an InSAR track and the interferogram itself. The line of sight (LOS) component of the GPS displacements (Table 2) is calculated by the scalar product of the east, north, and up data, with a unit vector pointing in direction of the radar (satellite look angle ranges between 19.4 and $23.4^{\circ}$ depending on position of GPS station within the track; azimuth for the ascending pass is $\sim-13^{\circ}$, for the descending pass $\sim-167^{\circ}$ clockwise from north). The difference between the GPS and InSAR LOS at the location of each GPS site is then minimized by fitting a number of full phase offsets $n \times 2 \pi$ (with $n$ being the number of missing phases) to the InSAR data. Figure 7 shows the original and the phase-corrected data for the interferograms used in this study. The selection criteria are a short time span before and after the earthquake, high coherence, and little noise (e.g., long-wavelength signal from orbital errors).

The ascending interferogram has a time span of 5 years (02 September 2004 to 27 August 2009), and interseismic deformation between 2004 and 2009 could significantly reduce the observed coseismic displacements. Therefore, we correct the data from the ascending interferogram for interseismic strain accumulation using our GPS-based model results, presented below. This step is performed before the
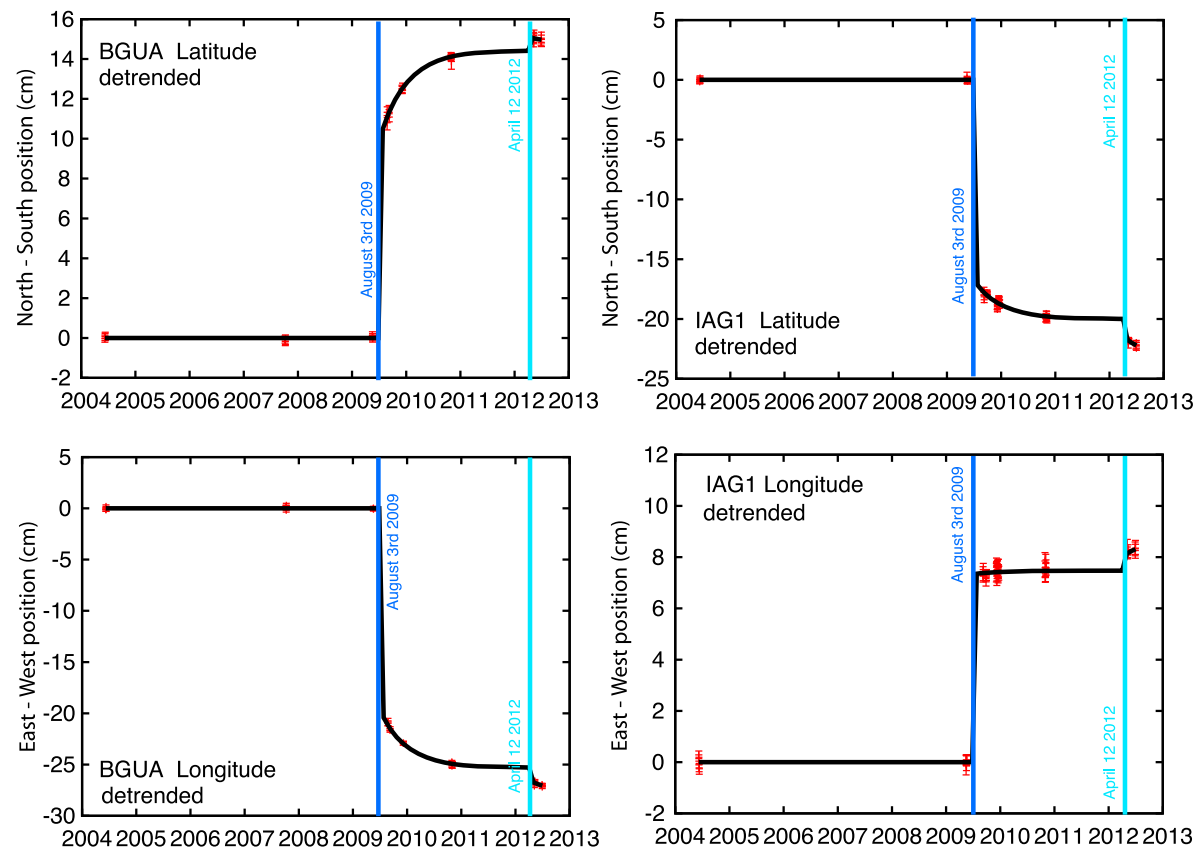

Figure 6. Detrended time series of GPS stations (left) BGUA and (right) IAG1 showing accelerated velocities and postseismic relaxation following the 3 August 2009 earthquake. 


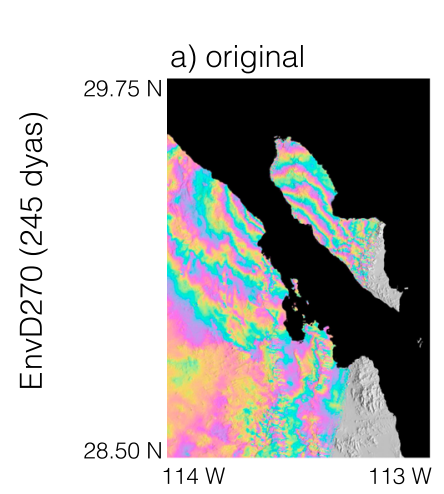

d) original

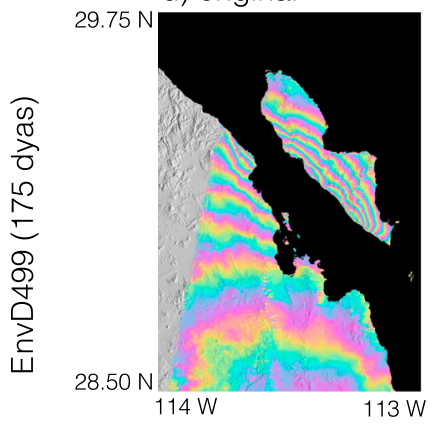

g) original

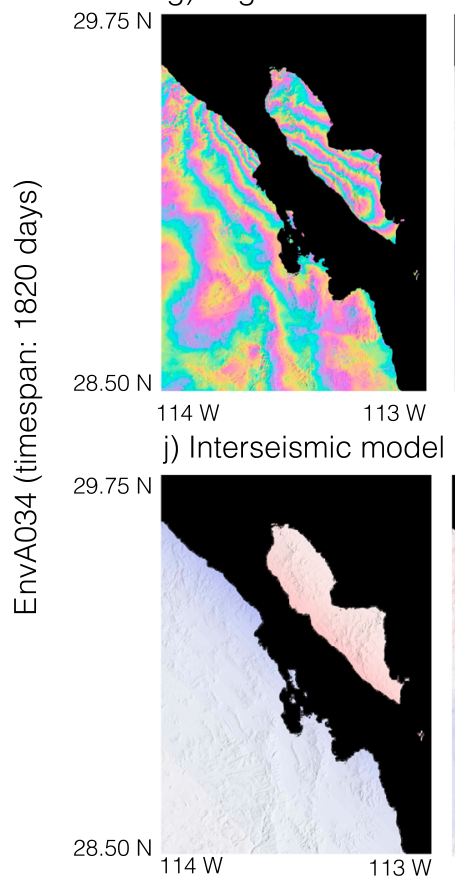

b) unwrapped original

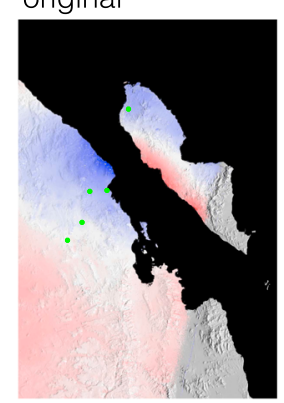

e) unwrapped original

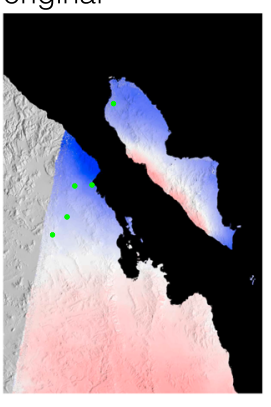

h) unwrapped original

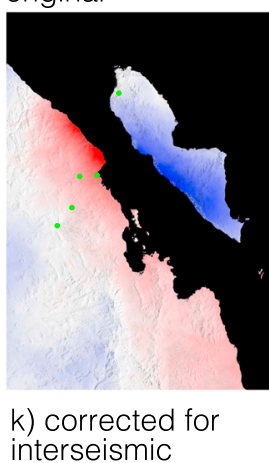

c) corrected for phase-offset from GPS

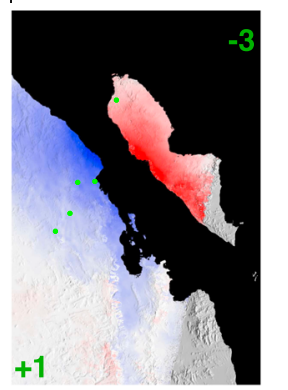

f) corrected for phase-offset from GPS

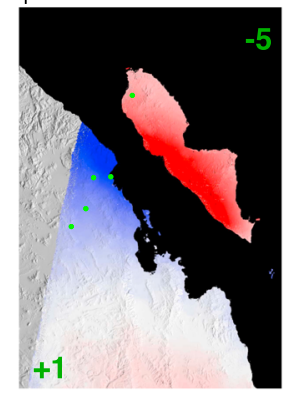

i) corrected for phase-offset from GPS

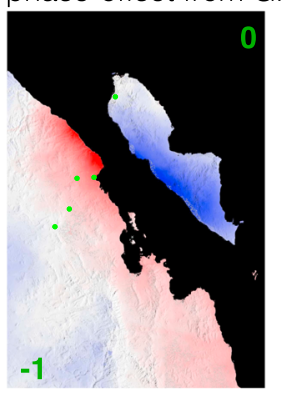

I) corrected for interseismic and phase-offset from GPS
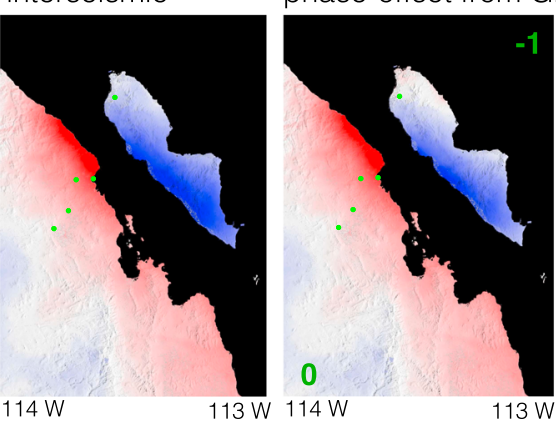
in

LOS displacement [radians]

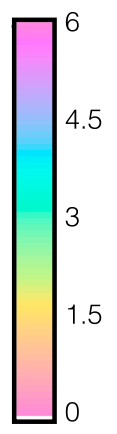

Ground displacement [m] LOS direction

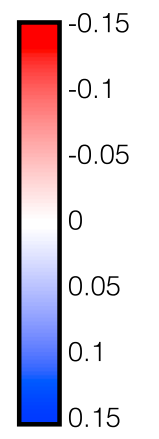

Figure 7. Data from Envisat satellite interferograms of (a-c) descending track 270 (21 March 2009 to 12 September 2009) and (d-f) track 499 (06 April 2009 to 28 September 2009) and (g-l) ascending track 034 (02 September 2004 to 27 August 2009). All data are corrected for constant phase offset at Baja California and Angel de la Guarda Island using the GPS displacement data. For the ascending interferogram we additionally apply a correction for interseismic strain accumulation from the Ballenas Fault based on model results shown in Figure 8 due to the long time span of the interferogram.

phase offset correction (Figures $7 \mathbf{j}-7 \mathrm{ll}$ ). To test the effect of a potential bias from the interseismic correction, we also invert a coseismic deformation model using data from the ascending interferogram that was not corrected for interseismic strain accumulation (Figure 7i). The difference between the two data sets, after the final phase-offset correction, is $2 \mathrm{~cm}$ on Angel de la Guarda Island and $6 \mathrm{~cm}$ on peninsular Baja 


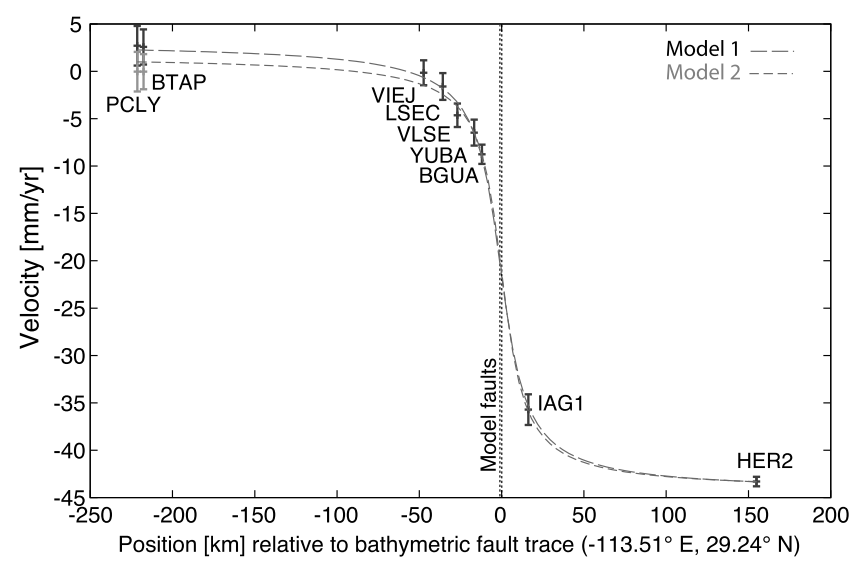

Figure 8. Interseismic GPS velocity data projected in fault-parallel direction $\left(312^{\circ}\right)$ along a profile perpendicular to the Ballenas Fault (Figure 4, profile from west to east) and best fitting interseismic velocity models (the dotted lines show end-member models 1 and 2) for strain accumulation at a vertical strike-slip fault in an elastic half-space [Savage and Burford, 1973]. Location of model fault is shown as dashed line.
California for the maximum displacement found in each interferogram. We did not correct the descending interferograms for interseismic deformation because the effect is small due to their short time span of 6 month (EnvD2 track 270 21 March 2009 to 12 September 2009 and EnvD2 track 49906 April 2009 to 29 September 2009). The overall displacement patterns are discussed in section 5 .

\section{Interseismic Data Analysis}

\subsection{Interseismic Velocity Field}

Figure 4 shows the GPS velocity field during the interseismic period in stable Baja California reference frame. Because rigid rotation of the Baja California microplate is subtracted, any remaining motion within the microplate indicates

internal deformation. Significant internal deformation is observed at sites adjacent to the Ballenas Channel, where the site velocities point in North America-Baja California relative plate motion direction, and rates increase as the distance to the fault decreases (maximum rate at BGUA is $8.8 \pm 1.4 \mathrm{~mm} / \mathrm{yr}$ ). On the opposite site of the Ballenas Fault, GPS station IAG1 shows a large relative motion with respect to Baja California $(35.7 \pm 2.3 \mathrm{~mm} / \mathrm{yr})$ but significantly lower than that of site HER2 on mainland Mexico $(43.3 \pm 0.7)$. The observed velocity field is consistent with strain accumulation on a locked, right-lateral strike-slip fault within the Ballenas Channel. Sites on Vizcaino peninsula show insignificant velocities due to the large uncertainties. The measurements may, however, be affected by strain accumulation from the ToscoAbreojos Fault to the west of our network and bias the far-field rate of our model results (velocities are significant at the 1 sigma error level; Table 1). Therefore, we consider three end-member models. In the first model we use the observed velocities; in the second model we assume the velocities at BTAP and PCLY to be zero, i.e., in perfect agreement with rigid Baja California rotation; in the third model we do not include these sites at all.

\subsection{Interseismic Strain Accumulation Modeling}

Interseismic strain accumulation is modeled along a profile across the Ballenas Channel, oriented perpendicular to the fault trace (Figure 4). We project the location of GPS stations onto the profile and project the GPS horizontal velocities in the fault-parallel direction (Figure 8). The GPS uncertainty ellipse is also projected in the fault-parallel direction, following Plattner et al. [2013] and Hackl et al. [2013]. To fit the data we use a screw dislocation model in an elastic half-space [Savage and Burford, 1973]. The model assumes a single vertical fault, locked from the surface to a locking depth $D(\mathrm{~km})$, moving at a fault slip rate $V(\mathrm{~mm} / \mathrm{yr})$. We also estimate a constant velocity offset $v n(\mathrm{~mm} / \mathrm{yr})$ to correct for the GPS reference frame and horizontal fault position $x(\mathrm{~km})$ to compare the model fault location to the bathymetric fault trace across our profile $\left(-113.55^{\circ} \mathrm{E}, 29.27^{\circ} \mathrm{N}\right)$. To find the best fitting model parameters, we minimize the weighted sum of squares of residuals. The model results and misfit are summarized in Table 3.

Table 3. Interseismic Fault Slip Rate $(V)$, Locking Depth $(D)$, Distance From Fault $(x)$, and Model Misfit (RMS)

\begin{tabular}{lcccc} 
Model & $V(\mathrm{~mm} / \mathrm{yr})$ & $D(\mathrm{~km})$ & $x(\mathrm{~m})^{\text {a }}$ & $\chi^{2}$ Reduced \\
\hline 1 & $47.5 \pm 0.8$ & $11.7 \pm 1.0$ & -700 & 0.3 \\
2 & $46.0 \pm 0.9$ & $10.4 \pm 1.5$ & -20 & 0.5 \\
3 & $47.0 \pm 1.2$ & $11.3 \pm 1.4$ & -510 & 0.5 \\
\hline
\end{tabular}

${ }^{\mathrm{a}}$ Distance to bathymetric fault trace at $-113.55^{\circ} \mathrm{E}, 29.27^{\circ} \mathrm{N}$ (Figure 2). 

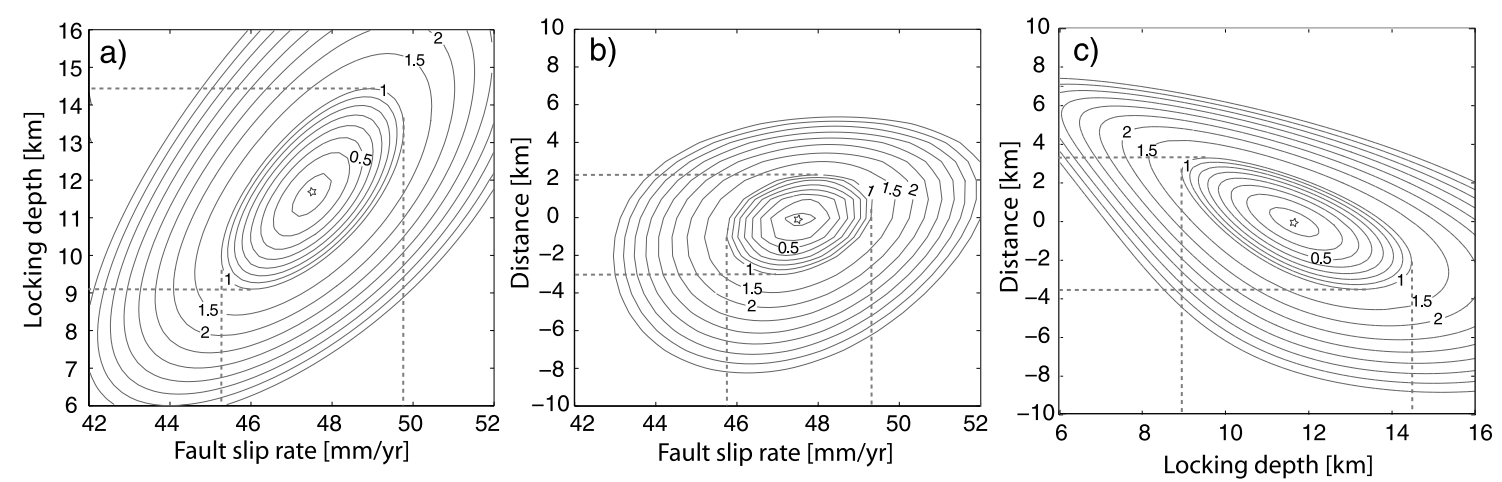

Figure 9. (a-c) Two-dimensional distribution of reduced $\chi$-square misfit showing trade-off effects of model fit for the three independent model parameters fault slip rate, fault locking depth, and distance from fault. Reduced $\chi$-square misfit of 1 corresponds to $58 \%$ confidence interval, of $\sim 2$ to $95 \%$ confidence interval.

In our first model we use the observed velocities for GPS sites BTAP and PCLY at Vizcaino peninsula. Our best fitting model shows a good fit to the data (Figure 8) with a reduced $\chi^{2}$ misfit of 0.3 . The estimated fault slip rate is $V=47.5 \pm 0.8 \mathrm{~mm} / \mathrm{yr}$, and fault locking depth $D$ is $11.7 \pm 1.0 \mathrm{~km}$. The model fault is located $700 \mathrm{~m}$ southwest of the bathymetric trace.

In our second model we assume the velocities of GPS sites BTAP and PCLY to be zero. We obtain a fault slip rate of $46.0 \pm 0.9 \mathrm{~mm} / \mathrm{yr}$ and a fault locking depth of $10.4 \pm 1.5 \mathrm{~km}$. The model fault position agrees with the bathymetric trace within $20 \mathrm{~m}$. The model fit is comparable to the previous solution (Figure 8) with a reduced $\chi^{2}$ misfit of 0.5 .

In our third model, we do not include sites BTAP and PCLY. We obtain a fault slip rate of $47.0 \pm 1.2 \mathrm{~mm} / \mathrm{yr}$ and a fault locking depth of $11.3 \pm 1.4 \mathrm{~km}$. The fault position is $510 \mathrm{~m}$ southwest of the bathymetric fault trace. The reduced $\chi^{2}$ misfit is again 0.5 .

Above, we refer to the 1 sigma uncertainties of each parameter that we obtain from the inversion of the faultparallel component of the velocity, assuming uncorrelated uncertainties. To investigate the effect of correlated uncertainties we perform a grid search (using the observed GPS velocities for BTAP and PCLY) to find the best fitting pairs of $V$ and $D, V$ and $x$, and $D$ and $x$, constraining the third parameter from the best fit solution of model 1. The distribution of the reduced $\chi^{2}$ mistfit (Figure 9) shows that all three parameters $(V, D$, and $X)$ are well constrained and trade-off effects are moderate. At the 1 sigma confidence interval, the fault slip rate is between $45.8 \mathrm{~mm} / \mathrm{yr}$ and $49.3 \mathrm{~mm} / \mathrm{yr}$ (Figures $9 \mathrm{a}$ and $9 \mathrm{~b}$ ), fault locking depth between $9 \mathrm{~km}$ and $14.5 \mathrm{~km}$ (Figures 9a and 9c), and the fault location fits to the bathymetric fault trace within $3.8 \mathrm{~km}$ (Figures 9b and 9c).

Fault dip does not influence the surface deformation pattern and thus does not affect the best fitting fault parameters [Segall, 2010].

\section{Coseismic Displacement Analysis}

\subsection{Coseismic Displacement Fields}

Figure 5 shows the GPS horizontal displacement field during the coseismic and early postseismic periods (Table 2). All sites within the Baja California peninsula show significant northwest-directed displacements (azimuth $276.5^{\circ}-297.6^{\circ}$ ), with the magnitude decreasing as the distance from the Ballenas Channel increases. BGUA, located $\sim 12 \mathrm{~km}$ from the fault, records the highest displacement of $25.99 \mathrm{~cm} \pm 0.14 \mathrm{~cm}$, while VIEJ, located at $\sim 48 \mathrm{~km}$ distance from the fault, records only $6.13 \mathrm{~cm} \pm 0.20 \mathrm{~cm}$. Motion of the GPS site on Angel de la Guarda Island is directed south-southeast (IAG1 records $19.44 \mathrm{~cm} \pm 0.21 \mathrm{~cm}$ at $159.4^{\circ}$ clockwise from north). Five of six GPS stations showed insignificant vertical displacement. Only site BGUA shows a significant vertical deformation signal $(4.7 \mathrm{~cm} \pm 0.30 \mathrm{~cm})$, small in comparison to the horizontal deformation. The GPS deformation pattern is compatible with a right-lateral offset along a strike-slip fault located within the Ballenas Channel.

Figures $7 c, 7 f, 7 i$, and $7 l$ show the resulting displacement fields from the selected SAR interferograms, after corrections for phase offset and interseismic deformation. To first order, the deformation patterns are axi-symmetric across the Ballenas Channel. Descending images show negative LOS signal on peninsular 
Baja California and positive LOS signal on Angel de la Guarda Island, while ascending images show the opposite sign in the LOS signal. On peninsular Baja California, the highest displacement magnitudes are at the northern margin of the Ballenas Channel. The maximum LOS change is $\sim 17 \mathrm{~cm}$ in descending track 270 (Figure $7 \mathrm{c}$ ) and $\sim 22 \mathrm{~cm}$ in the ascending track after correction for interseismic strain accumulation (Figure 7l). On Angel de la Guarda Island, the highest displacement magnitudes are along the central margin bordering the Ballenas Channel, with $\sim 20 \mathrm{~cm}$ for descending track 270 (Figure $7 \mathrm{c}$ ) and $\sim 18 \mathrm{~cm}$ for the ascending track. For both island and peninsular sites, displacements decrease with distance from the Ballenas Channel, and the displacement field is compatible with a right-lateral strike-slip event along a northwest-southeast striking fault located within the Ballenas Channel.

\subsection{Coseismic Displacement Modeling}

For the modeling procedure we subsample the InSAR data using regular gridding with an $\sim 1 \mathrm{~km}$ resolution in the near field $(100 \times 100$ pixel) and an $\sim 2 \mathrm{~km}$ in the far field $(50 \times 50$ pixel). The regional mask is shown in Figure 10. We obtain 1456 data points for descending track 270, 1625 data points for descending track 499, and 1277 data points for the ascending track. Our choice of a regular grid is explained by the limited data availability in this marine setting masking large parts of the near field and making other sampling algorithms less preferable. We assign relative weighting to the interferograms based on the assessment of how well each data set can describe right-lateral strike-slip faulting on the Ballenas Fault (using a fixed fault strike of $312^{\circ}$, dip of $90^{\circ}$, and a fault plane extending to the surface in order to reduce the number of free parameters; Figure S1 in the supporting information). Thereby, we use the inverse RMS relative to the sum of the RMS of all models as a weighting factor. Our relative weighting is $37 \%$ for track D270, $40 \%$ for D499, and 20\% for A034. The GPS data are weighted with $3 \%$ only, because using high weighting, the spatial distribution of our stations along a single profile biases the results of our three-dimensional model. We discuss implications of different weighting assumptions below.

The coseismic displacement model is a rectangular dislocation in a homogenous, isotropic, elastic half-space [Okada, 1985]. Initially we solve for uniform slip but later derive spatially variable slip for our preferred model geometry. The dislocation model uses eight parameters, with inversion boundaries (Table 4) approximating the central moment tensor solution of the main shock, precise epicentral locations and the subsequent estimated rupture area [Castro et al., 2011], the mapped fault geometry [Lonsdale, 1989], and the azimuth of Baja California-North America geodetic plate motion [Plattner et al., 2007]. Simultaneously with the deformation source, we solve for phase ramps for each averaged interferogram representing longwavelength tropospheric delay variations [Fattahi and Amelung, 2014]. The best fitting model is found by inversion of the displacement fields from the three interferograms (considering the incidence angles at our data points), and of the horizontal and vertical GPS data, using a Monte Carlo-type simulated annealing algorithm [Cervelli et al., 2001].

Our preferred uniform slip model (Table 4, model 1) shows a good fit to the data. The model fault is located within Ballenas Channel (fault center latitude $=29.22^{\circ} \mathrm{N}$, fault center longitude $=-113.48^{\circ} \mathrm{E}$ ) and oriented quasi-parallel to the Ballenas Transform (strike $=310^{\circ}$ ). The model fault extends from the southeastern margin of the Ballenas Basin $65 \mathrm{~km}$ northwest toward the southwestern edge of the Lower Delfin Basin but terminates about $30 \mathrm{~km}$ southeast of it. The dimensions of the best fitting fault plane imply surface rupture of a vertically orientated fault $\left(\mathrm{dip}=90^{\circ}\right)$ down to depth of $13 \mathrm{~km}$. The uniform slip model has a strike-slip offset of $1.4 \mathrm{~m}$. We obtain an earthquake magnitude of $M_{w} 7.0$, with the geodetic moment being $3.38 \times 10^{19} \mathrm{Nm}$ (assuming a shear modulus of $30 \mathrm{GPa}$ ).

The residual motion is small, considering that the homogenous slip model does not take into account naturally occurring variations in slip distribution on the rupture surface, such as slip tapering and changes in rake, or geometrical complexities of the rupture plane, such as fault bends or multiple fault segments (Figure 10). The long-wavelength signal can also result from atmospheric noise. For the ascending interferogram we can exclude that the long-wavelength signal is caused by the interseismic strain correction because we see a similar pattern for an uncorrected interferogram (Figure S1). Testing for a multiple fault planes did not improve the model solution enough to justify the increased number of model parameters.

To address the model uncertainties, we refer to the probability density functions obtained from Gibbs sampling (Figure 11). Most parameters are tightly constrained; only rupture depth and slip show larger 


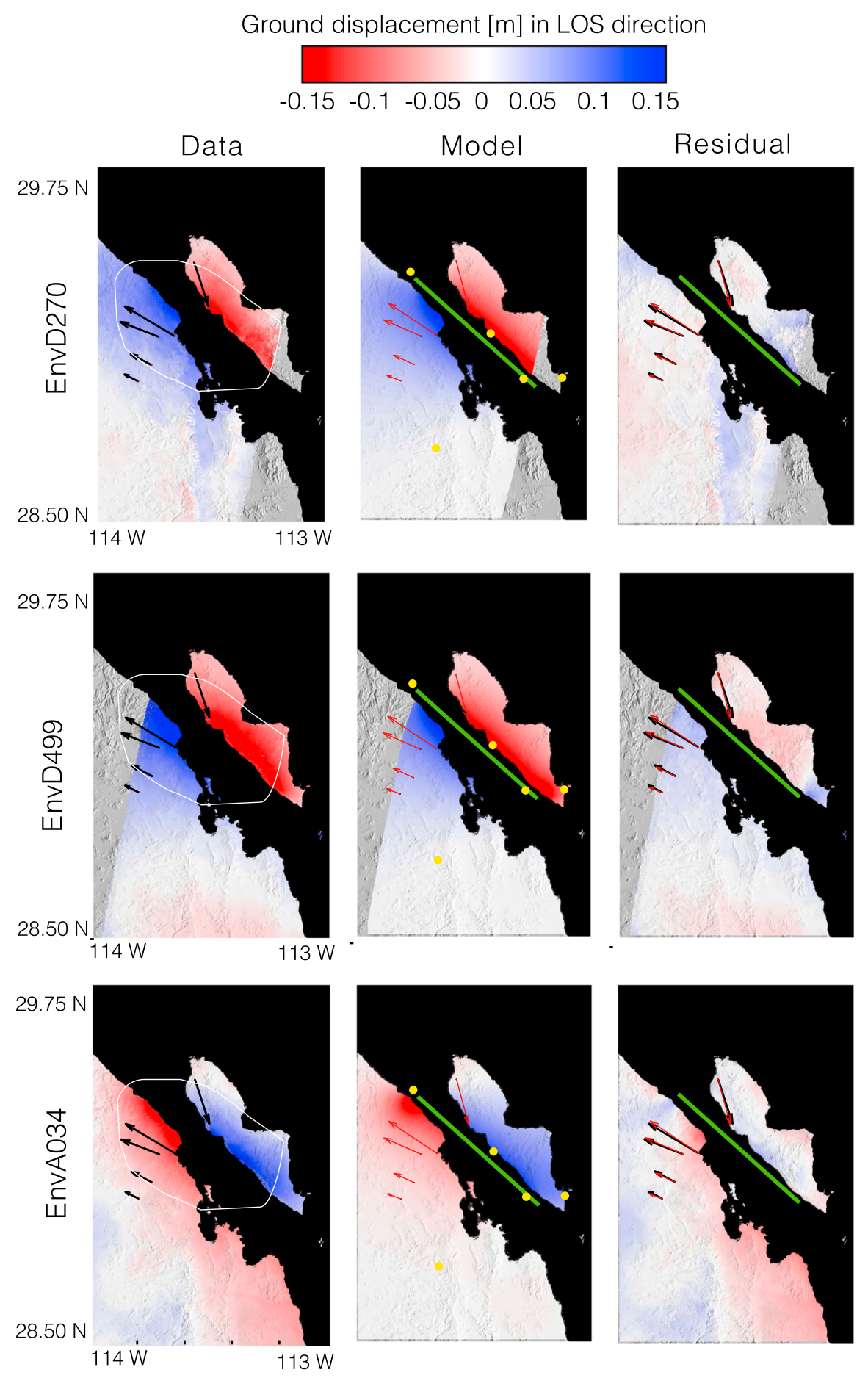

Figure 10. Data (the white polygon shows the outline of grid sampling mask for higher resolution of near field), model (uniform slip model 1 in Table 3), and residual of line of sight displacement field from Envisat satellite interferograms of (top) descending tracks 270 (21 March 2009 to 12 September 2009) and (middle) 499 (06 April 2009 to 28 September 2009) and (bottom) ascending track 034 (02 September 2004 to 27 August 2009). Observed and modeled horizontal GPS displacement vectors are shown in black and red. The green line shows the near-vertical model fault surface. The yellow dots in the model column show the location of the main shock and the major foreshock and aftershock [Castro et al., 2011]. 
Table 4. Fault Location, Geometry, and Slip From Coseismic Deformation Modeling (This Study) and Rupture Surface Parameters From Seismic Data Analysis

\begin{tabular}{|c|c|c|c|c|c|c|c|c|c|c|c|}
\hline RMS (mm) & $\mathrm{I}(\mathrm{km})$ & $d(\mathrm{~km})$ & $h(\mathrm{~km})$ & $\delta$ (deg) & $s(\mathrm{deg})$ & Longitude $\left({ }^{\circ} \mathrm{E}\right)$ & Latitude $\left({ }^{\circ} \mathrm{N}\right)$ & $s s(m)$ & $d s(\mathrm{~m})$ & $M_{w}$ & Mo $(\mathrm{Nm})$ \\
\hline \multicolumn{12}{|c|}{ Inversion boundaries (min, $\max$ ) } \\
\hline & 40100 & 520 & $0-5$ & $85^{\circ}, 95^{\circ}$ & $120^{\circ}, 140^{\circ}$ & $-113.6^{\circ},-113.4^{\circ}$ & $29.2^{\circ}, 29.3^{\circ}$ & & $<0.5$ & & \\
\hline \multicolumn{12}{|c|}{ (1) Uniform slip model } \\
\hline \multicolumn{12}{|c|}{ (2) Uniform slip model with dip slip } \\
\hline 21.9 & 65 & 11 & 0 & 86 & 130 & -113.48 & 29.22 & 1.6 & 0.1 & 7.0 & $3.29 \times 10^{1 \varsigma}$ \\
\hline \multicolumn{12}{|c|}{ (3) Uniform slip model without correcting ascending interferogram for interseimic signal } \\
\hline 21.3 & 65 & 11 & 0 & 86 & 134 & -113.48 & 29.22 & 1.5 & - & 7.0 & $3.11 \times 10^{1 \mathrm{c}}$ \\
\hline \multicolumn{12}{|c|}{ Global CMT } \\
\hline & & & $12.2^{\mathrm{a}}$ & 87 & 311 & -113.53 & 29.22 & 1.78 & & 6.9 & $2.55 \times 10^{15}$ \\
\hline \multicolumn{12}{|c|}{ Castro et al. [2011] } \\
\hline & 43 to 100 & 10 to 14 & $13.7^{\mathrm{a}}$ & & & -113.42 & 29.21 & 1.3 & & & $2.59 \times 10^{1 \mathrm{~s}}$ \\
\hline
\end{tabular}

\footnotetext{
${ }^{\mathrm{a}}$ Hypocenter depth/focal depth.
}

uncertainties. On the $95 \%$ confidence interval ( 2 sigma uncertainties) the rupture width is between 12 and $14 \mathrm{~km}$, strike slip between 1.4 and $1.5 \mathrm{~m}$.

Different weighting assumptions influence parameters of the best fitting model parameters. The sensitivity of each model parameter to the relative weighting can be estimated by comparing the solutions obtained from modeling only one data set at a time (Figure S1). In general, it can be said that model fault length varies between 50 and $75 \mathrm{~km}$, the strike between $129^{\circ}$ and $138^{\circ}$. The dip and the location of the fault center location vary insignificantly. The parameter that is most sensitive to the data weighting assumptions is the fault depth, which can vary between 7 and $18 \mathrm{~km}$. Difference in fault width implies a change in the slip (1.1 and $2 \mathrm{~m}$ ). In all models, the resulting fault width was close or equal ( $<1 \mathrm{~km}$ difference) to the fault depth, implying that (near-) surface rupture provides the best fit to the data. However, lack of observations within a few kilometers from the fault means that we cannot confirm surface rupture. The overall deformation pattern of models with different weighting assumptions does not differ greatly from the results shown in Figure 10.
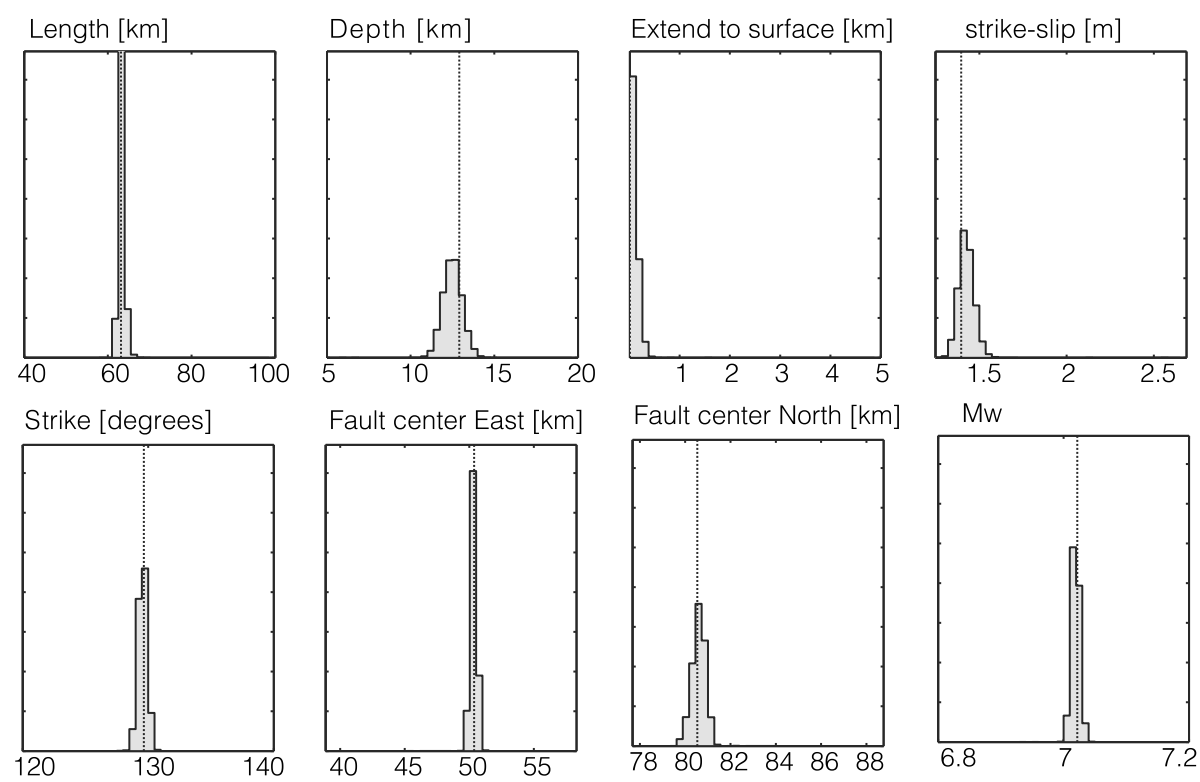

Figure 11. Probability density functions obtained from Gibbs sampling using 50,000 sweeps at a temperature of -1 . The dotted lines show the best fit solution. Best fit fault center solution is at $-113.48^{\circ} \mathrm{E}, 29.22^{\circ} \mathrm{N}$. 


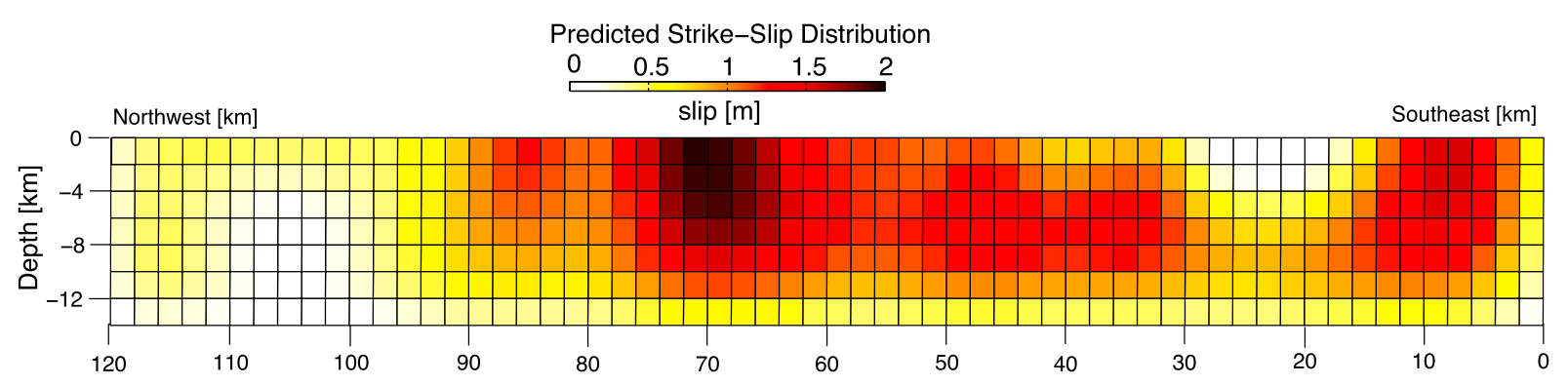

Figure 12. Predicted strike-slip distribution along the $120 \mathrm{~km}$ long and $14 \mathrm{~km}$ wide fault plane with a slip maximum of $1.9 \mathrm{~m}$. Fault center location at $60 \mathrm{~km}$ as shown in Figures 2 and $3\left(-113.48^{\circ} \mathrm{E}, 29.22^{\circ} \mathrm{N}\right)$.

We also tested models with a dip-slip component (Table 4, model 2) and a model for which the ascending interferogram was not corrected for interseismic strain accumulation (Table 4, model 3). For both, we find that the inversion results are similar to model presented above. The residuals for a model in which the ascending interferogram was not corrected for interseismic strain accumulation show that the model underestimated westward motion of Baja California and eastward motion of Angel de la Guarda Island (best seen for comparison of modeled and observed GPS vectors).

Based on the well-constrained model parameters fault center location, strike, and dip (Table 4), we calculate the best fitting slip distribution on the fault plane. We extend the fault plane to be $120 \mathrm{~km}$ long in order to account for aftershocks in the Lower Delfin Basin. In depth we allow slip down to $14 \mathrm{~km}$ (approximating the coseismic rupture width). The fault surface is divided into patches of dimension $2 \times 2 \mathrm{~km}$. At each fault patch we solve for the strike-slip magnitude only, because the small component of dip slip inferred in model 1 did not improve the model misfit heavily. We test different degrees of surface roughness, with increasing slip variation reducing the misfit (Figure S2). Our preferred solution is picked for a smoothing at which the misfit decrease has just converged as described in Jonsson et al. [2002] and has a mean roughness of $8.8 \mathrm{~cm} / \mathrm{km}$. As expected, the RMS is for this model smaller than for the uniform dislocation model (Table 4). The slip distribution pattern (Figure 12) shows that most slip occurs above $10 \mathrm{~km}$ depth, with the fault slip maximum of $2 \mathrm{~m}$ between 2 and $6 \mathrm{~km}$ depth, about $10 \mathrm{~km}$ northwest of the fault center

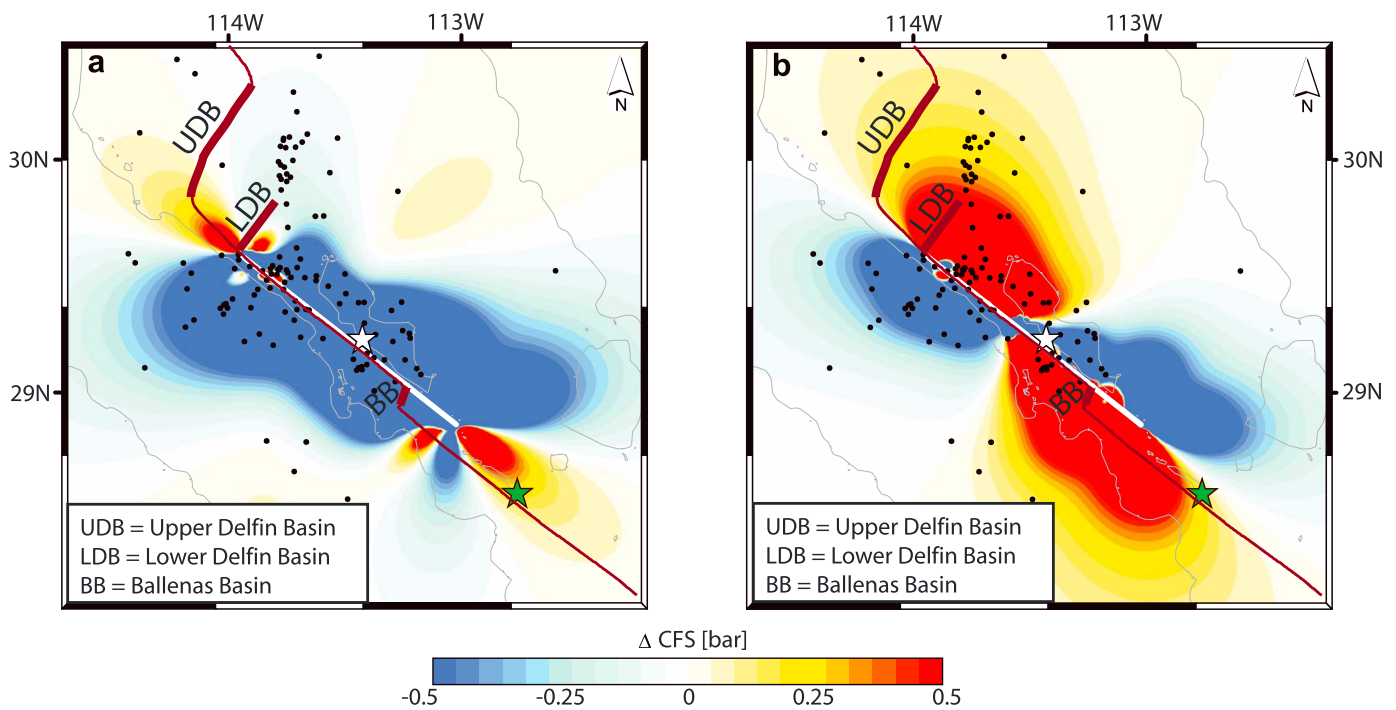

Figure 13. Coseismic $\triangle$ CFS resulting from right-lateral offset along the Ballenas Fault (white line) with slip distribution as shown in Figure 12 calculated on (a) the orientation of the Gulf of California transform faults $\left(312^{\circ}\right)$ at depth of $10 \mathrm{~km}$ and (b) the orientation of the basins (perpendicular to transforms) at depth of $10 \mathrm{~km}$. Red color indicates increased probability for failure, blue indicates decrease. The black dots are aftershocks from Castro et al. [2010]. The white star shows the location of the 2009 earthquake, and the green star shows the location of the $2012 M_{w} 6.9$ earthquake. 
Table 5. Estimates of Relaxation Time Derived From Postseismic GPS Measurements

\begin{tabular}{lccc} 
Site & Best Relaxation Time (Days) & Reduced Chi-Square & WRMS (mm) \\
\hline IAG1 & 120 & 0.64 & 1.1 \\
BGUA & 178 & 0.79 & 1.7 \\
YUBA & 194 & 0.81 & 1.3 \\
VLSE & 186 & 0.75 & 1.3 \\
LSEC & 195 & 1.1 & 1.9 \\
\hline
\end{tabular}

(Table 4). While in the northwest there is only little displacement beyond $30 \mathrm{~km}$ from the fault center, in the southeast we find $>1.0 \mathrm{~m}$ slip to extend beyond the Ballenas Basin (extent of the $120 \mathrm{~km}$ fault plane is shown in Figure 12). The geodetic moment is $3.96 \times 10^{19}$.

\subsection{Coulomb Stress Change}

We use the distributed slip model to calculate the Coulomb stress changes produced by the main event and the nearby aftershocks using the software Coulomb 3.3 [Toda et al., 2011]. The change in Coulomb failure stress ( $\Delta$ CFS) is defined as $\Delta$ CFS $=\Delta \tau-\mu^{\prime} \Delta \sigma_{n}$ [King et al., 1994], where $\Delta \tau$ is the change in shear stress, $\mu^{\prime}$ is the coefficient of effective friction, and $\Delta \sigma_{n}$ is the change in normal stress. A positive $\Delta C F S$ indicates that the receiver fault has been brought closer to failure, while a negative $\Delta$ CFS means that the next rupture has been delayed. We carried out coseismic $\triangle$ CFS calculations on the geometry and expected kinematics of nearby transform faults (Figure 13a) and normal faults bordering the basins perpendicular to the transform faults (Figure 13b). The earthquake did slightly ( 0.2 bar) increase the stress on the transform fault south of the Ballenas (Figure 13a) and may have triggered the April $2012 M_{w} 6.9$ event at the northern end of the Guaymas Fault segment (Figure 1). A larger Coulomb stress increase ( 0.5 bar) is registered on the normal faults bounding the Ballenas Basin to the south and the Lower Delfin basin to the north (Figure 13b). The latter in particular is characterized by several aftershocks that, according to our modeling, may have been triggered by the stress changes produced by the 2009 main shock.

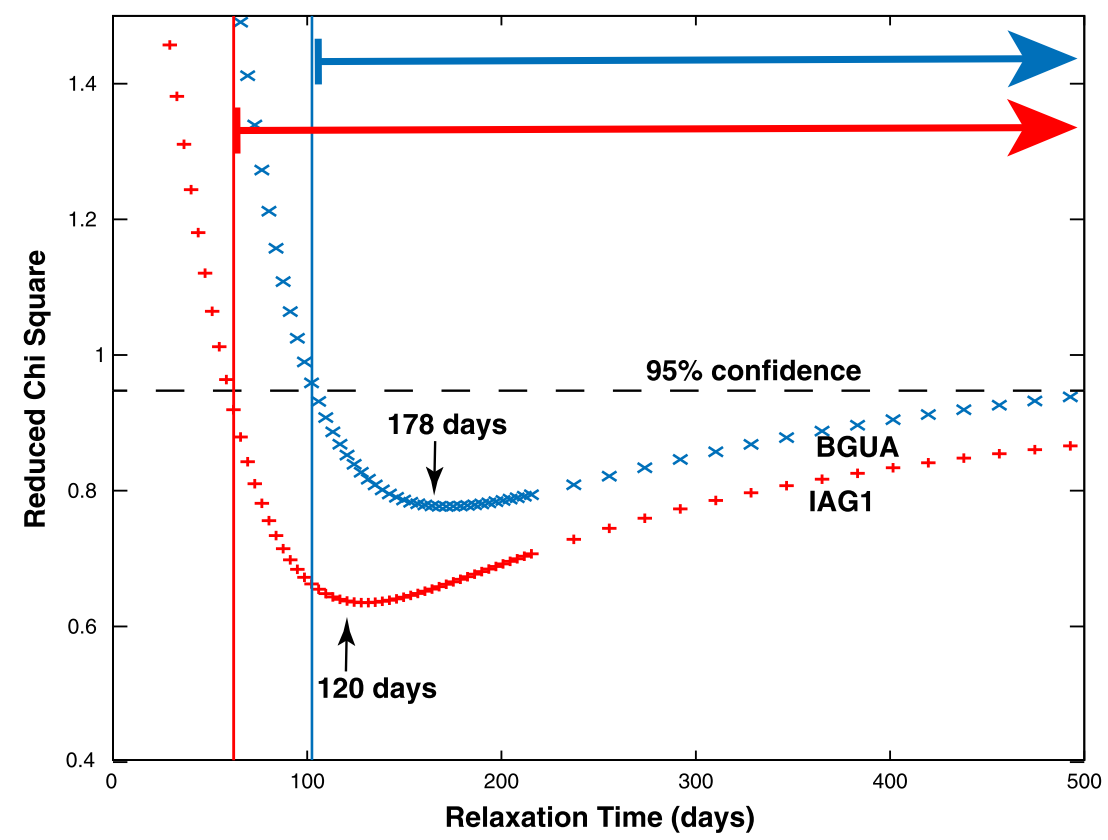

Figure 14. Reduced chi-square for the fit of the time series of BGUA (blue) and IAG1 (red) as a function of the relaxation time. The best fit relaxation time for the two sites is 178 and 120 days, respectively. The blue and red arrows at the top represent the values of relaxation times that are statistically compatible with the fit of the time series within a $95 \%$ confidence interval. 


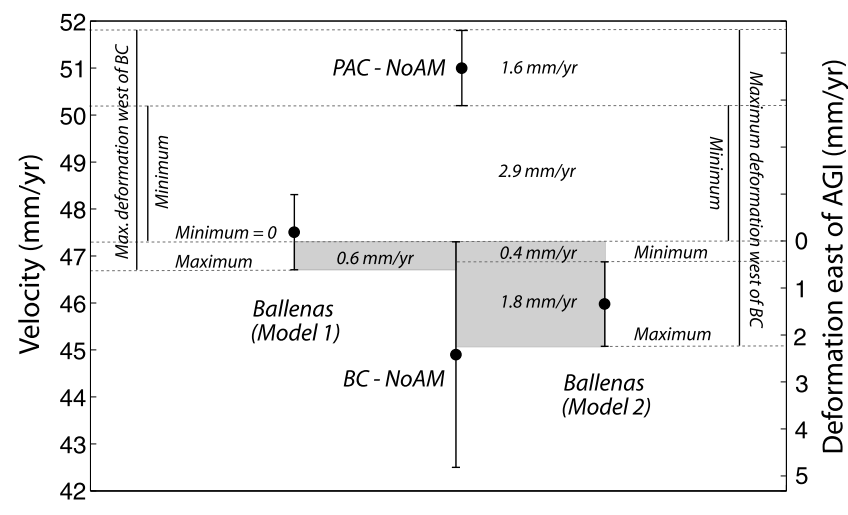

Figure 15. Comparison of Ballenas Fault slip rates (highest and lowest rate estimates) with Baja California-North America (BC-NoAM) [Plattner et al., 2007] and Pacific-North America (PAC-NoAM) [DeMets et al., 2010] plate relative motion and implications for deformation rates east of Angel de la Guarda Island (AGI) (dark grey shaded areas) and west of Baja California (BC) peninsula (indicated by vertical bars).

\section{Postseismic Relaxation}

The sites LSEC, VLSE, YUBA, BGUA, and IAG1 present a very strong postseismic signal (e.g., Figure 6). Assuming an exponential decay of the signal, we can invert the time series for the three components (north-south, east-west, and up-down) of each station for a single best fit relaxation time following Malservisi et al. [2015]. The best fit relaxation time for the sites within the Baja peninsula varies from 178 to 195 days (Table 5). For IAG1 (located on Isla Angel de la Garda) the best fit relaxation time is 120 days. However, the length of the time series and the presence of a second earthquake in 2012 limit our ability to constrain the upper bounds of the relaxation time. The lower bounds are well constrained (Figure 14). Although statistically all the best values are equal within uncertainties, the analysis shows the possibility that the relaxation time for the sites close to (or within) the Gulf of California have lower relaxation times. This would imply some rheological asymmetry across the Ballenas Fault.

\section{Discussion}

The Gulf of California has long been the focus of measurements of relative motion between the Pacific and North American plates because the width of plate boundary zone here is small compared to the continental San Andreas system to the north [Vacquier and Whiteman, 1973; Dixon et al., 1991]. While the initial optical parallax measurements of Vacquier and Whiteman [1973] were not able to obtain a satisfactory result due in part to atmospheric effects, and the geodetic measurements presented here are nearly 2 orders of magnitude more precise than those early measurements, it is interesting to note that uncertainties associated with atmospheric propagation still represent a significant fraction of the error budget for modern space geodetic techniques.

Detailed studies of the well-exposed San Andreas system have led to an understanding of how relative motion is partitioned across various fault segments of this continental transform system and to some extent how this deformation evolves through time [e.g., Minster and Jordan, 1978; Argus and Gordon, 2001; Dixon et al., 1995, 2000b; Faulds et al., 2005a; Schmalzle et al., 2006; Plattner et al., 2010]. One of the conclusions from these studies is that the San Andreas Fault (in a strict sense) accommodates approximately $75 \pm 5 \%$ of total relative plate motion. In contrast, the Ballenas Transform accommodates at least $90 \%$ of Pacific-North America plate motion. We suspect that the difference is at least in part related to the setting of the latter within young oceanic crust, and locally high heat flow, which weakens the crust. The relatively shallow interseismic locking depth obtained in our study is consistent with this picture. The sections below present some additional implications of our findings.

\subsection{Interseismic}

The interseismic strain accumulation models fit the geodetic data well, and the low reduced $\chi^{2}$ misfit indicates that GPS uncertainties may be overestimated, as already observed by Hackl et al. [2011, 2013]. Data and models confirm that most of the Baja California-North America motion is accommodated at the Ballenas Fault, making it one of the fastest-slipping strike-slip segments between the Pacific and North American plates. Given its Pliocene age and total offset of $130 \mathrm{~km}$, deformation must have localized rapidly within the Ballenas Channel.

Our model slip rate has implications for the activity and deformation rate on faults east of Angel de la Guarda Island that formed during Proto-Gulf extension (Figure 15). The total deformation in the Gulf of California and 
coastal Sonora can be estimated from rigid plate motion between Baja California microplate and stable North America. At the fault location, this rate amounts to $44.9 \pm 2.4 \mathrm{~mm} / \mathrm{yr}$ [Plattner et al., 2007]. We subtract our model slip rate for the Ballenas Fault from the plate relative motion to estimate remaining deformation that must be accommodated east of Angel de la Guarda Island. Using our highest Ballenas Fault slip rate estimate of 47.5 $\pm 0.8 \mathrm{~mm} / \mathrm{yr}$ (model 1), the fault rate agrees with the relative plate motion rate within uncertainty. This implies that faults east of Angel de la Guarda Island are either inactive or deform at rates that in total do not exceed the overlap in slip rate considering uncertainties, i.e., $0.6 \mathrm{~mm} / \mathrm{yr}$. Using the lowest slip rate estimate of $V=46.0 \pm 0.9 \mathrm{~mm} / \mathrm{yr}$ allows a higher deformation rate of $2.2 \mathrm{~mm} / \mathrm{yr}$ and requires a minimum of $0.4 \mathrm{~mm} / \mathrm{yr}$ to be accommodated on faults east of Angel de la Guarda Island. These generally low rates agree with studies that documented the westward migration of motion in the Gulf of California, inactivity of faults in the Tiburon Basin and on the coast of Sonora, and low deformation rates $(<1 \mathrm{~mm} / \mathrm{yr})$ for faults on Tiburon Island [Gastil et al., 1975; Gastil and Krummenacher, 1977; Aragon-Arreola and Martin-Barajas, 2007; Martin-Barajas et al., 2013; Bennett et al., 2013]. Additional GPS data in central Baja California between site VIEJ and the Vizcaino peninsula, and on the islands east of the Ballenas Channel and in coastal Sonora, would provide better constraints on the slip rate of the Ballenas Fault, but our data clearly point to this fault accommodating the great majority of plate motion at this fault location.

Given the slip rate estimate for the Ballenas Transform we can also derive a better estimate for the maximum allowable deformation west of Baja California (Pacific-Baja California plate relative motion, e.g., ToscoAbreojos Fault [Dixon et al., 2000a]). To do so, we first calculate the full Pacific-North America plate motion from MORVEL $(51.0 \pm 0.8 \mathrm{~mm} / \mathrm{yr}$ [DeMets et al., 2010]) for the latitude of the Ballenas Fault. Then we subtract the maximum and minimum rates for Baja California-North America (based on the slip rate of the Ballenas Fault) to obtain the minimum and maximum slip rates of the Tosco-Abreojos Fault, giving $2.9 \mathrm{~mm} / \mathrm{yr}$ and $5.3 \mathrm{~mm} / \mathrm{yr}$ (model 1) and $6.9 \mathrm{~mm} / \mathrm{yr}$ (model 2) (Figure 15). For comparison, the Pacific-Baja California plate relative motion calculated at GPS site BTAP near the Tosco-Abreojos Fault, using a new Pacific-Baja California Euler pole that was calculated according to Plattner et al. [2007], augmented by our new data, is of $3.6 \pm 0.5 \mathrm{~mm} / \mathrm{yr}$ (Table S2). Additional measurements in and near the Vizcaino peninsula would also allow study of the interseismic strain accumulation from the Tosco-Abreojos Fault.

Our best fitting fault locking depth (between $11.7 \pm 1.0 \mathrm{~km}$ in model 1 and $10.4 \pm 1.5 \mathrm{~km}$ in model 2) is compatible with the base of seismicity at 10-15 km along transform faults in the northern and central Gulf of California [Goff et al., 1987; Castro et al., 2010, 2011; Sumy et al., 2013]. Our model result only defines fault location at our GPS transection. We suspect along-strike gradients in the locking depth along the Ballenas Faults (with lower locking depth in vicinity of the Ballenas Basin) due to variation in heat flow resulting from mantle upwelling beneath the basins [Wang et al., 2009]. Our limited data and simple elastic half-space models with homogenous rheology cannot resolve possible variations in the locking depth across the Ballenas due to variation in crustal thickness resulting from extension history [Lopez-Pineda et al., 2007; González-Fernández et al., 2005; Lizzeralde et al., 2007].

While our data are well fit by a single fault model, data uncertainties and lack of measurements close to the fault mean that we cannot preclude two or more closely spaced faults within the channel, separated by up to $10 \mathrm{~km}$. Within that distance, the number of faults does not affect our estimate of either fault locking depth or total slip rate, the latter being mainly constrained by the velocity of stations in the far field (BTAP, PCLY, and HER2).

\subsection{Coseismic}

Our best fit model confirms a right-lateral strike-slip event within the Ballenas Channel, and the fault location agrees with the bathymetric fault trace and the seismic centroid location within the joint uncertainty of the geodetic and seismic data sets. The fault strike agrees with the bathymetry data and with the direction of Baja California-North America rigid block motion at this latitude $\left(311^{\circ}\right)$. The fault length and orientation is in agreement with the locations of the major foreshock $\left(M_{w} 5.5\right.$, south of the epicenter) and aftershock ( $M_{w} 6.2$, north of the epicenter).

Our coseismic fault models have a rupture depth of $13 \mathrm{~km}$, equivalent within uncertainties to the seismic estimates of $10-15 \mathrm{~km}$ for the base of earthquake nucleation along transforms in the Gulf of California [Munguia et al., 1977; Goff et al., 1987; Castro et al., 2010, 2011; Sumy et al., 2013] but deeper than our estimates for the interseismic fault locking depth. Agreement between both parameters is not expected, 
because the two approaches estimate the depth of the brittle-ductile transition zone over different time scales. The comparison implies either that the rupture has propagated into the ductile zone or that our geodetic model includes afterslip or viscous deformation accommodated in or near the ductile zone during the early postseismic period following the earthquake. The latter is supported by the presence of a (later) postseismic relaxation signal in the GPS time series (Figure 6).

The geodetic moment of our uniform slip model is $3.38 \times 10^{19} \mathrm{Nm}$. This is $33 \%$ larger than the seismic moment of the main shock $\left(2.55 \times 10^{19} \mathrm{Nm}\right.$ reported by Global CMT catalog or $2.59 \times 10^{19} \mathrm{Nm}$ reported by Castro et al. [2011]) and 16\% greater than the sum of the main shock, foreshock, and major aftershock $\left(2.90 \times 10^{19} \mathrm{Nm}\right.$ derived from Global CMT catalog) (and greater if the moment of the distributed slip model of $3.96 \times 10^{19} \mathrm{Nm}$ would be used for comparison). This difference most likely reflects early postseismic deformation observed by the geodetic data that may be associated with aseismic transient deformation as afterslip, viscous, or poro-elastic deformation. As mentioned above, the presence of a later postseismic relaxation signal in the GPS time series supports this hypothesis (Figure 6). Unfortunately, lack of data in the period immediately after the earthquake do not allow a quantitative estimation of the early aseismic deformation, making it difficult to separate this signal from the coseismic deformation in our modeling. Data uncertainties and sensitivity of the inversion of both the geodetic and seismic data due to factors like unmodeled structural heterogeneity could also explain some of the difference. For example, it has been shown that the scalar moments of earthquakes in oceanic crust obtained by centroid moment tensor inversion have a standard deviation of 15\% [Hjörleifsdottir and Ekström, 2010].

It has been argued that the stress drop of 2.2 MPa derived from seismic analysis for this earthquake [Castro et al., 2011] was low in comparison to average stress drop for strike-slip earthquakes (6.0 MPa) [Allmann and Shearer, 2009]. Furthermore, it has been suggested that the discrepancy may be explained by slow rupture processes, not well recorded in the seismic data [Castro et al., 2011]. In this case, the geodetic slip model should show a greater moment because the deformation measurements are independent of the rupture speed causing them. Using our geodetic moment and the rupture length and width from our homogenous strike-slip model (Table 3), however, we calculate a stress drop of only 1.6 MPa [Lay and Wallace, 1995]. Thus, we argue that slow rupture processes cannot explain the discrepancy.

Acknowledgments

We thank our field assistants Miguel Navarro and Tito Valdez from Centro de Investigacion y Education Superior de Ensenada, Mexico, and G. Schmalzle for their help in developing and deploying the GPS network in Baja California. We thank our Editor and reviewer for their comments that helped to improve this manuscript. Additionally, we thank Scott Baker from UNAVCO, Nico Adam from DLR, and Henriette Sudhaus from University of Kiel. The GPS data used in this study are partially available from UNAVCO or e-mail rocco@usf.edu. InSAR data are available from WINSAR. Multibeam bathymetry data is accessibly archived in the MARGINS/ Gulf of California archive of the Marine GeoscienceData System (www.marine-geo.org). Funding for collection and interpretation of multibeam bathymetry came from NSF grants (OCE 02-03348 and OCE 06-46563) to PL. Funding for GPS campaign measurements came from the German Research Foundation under MA4163/1-1 and a National Science Foundation (NSF) grant to T.H.D. (OCE 0909075). We thank UNAVCO and WINSAR for helping with the InSAR data acquisition and InSAR and GPS data storage. C.P. was sponsored by a grant of the NSF tectonics program to F.A. (EAR-1019847) and a scholarship from the German Academic Exchange Service.
Sumy et al. [2013] showed that most large earthquakes within the Gulf of California are strike-slip events that occur along transforms and cluster at ridge-transform intersections. Basin extension may occur by aseismic processes, with some exceptions as observed in the Salsipuedes/Ballenas Basin in 2003 [Lopez-Pineda et al., 2014] (Figure 1). Our preferred model does have a dip-slip component; however, this component is very small, and good fit to the data is obtained with a pure strike-slip event (Table 4, model 2). Our model fault propagates into the Salsipuedes/Ballenas Basin, striking along the basin's eastern margin, and does not terminate at the ridge-transform intersection. Clustering of several smaller aftershocks was found north of the Ballenas Transform, at and beyond the Lower Delfin Basin (Figure 13), while the rupture process started by a moderate size foreshock south of the Salsipuedes/Ballenas Basin [Castro et al., 2011] (Figure 10).

\section{Conclusion}

We presented space-geodetic data from GPS and InSAR showing the surface deformation from interseismic strain accumulation and coseismic stress release from the 3 August $2009 M_{w} 6.9$ earthquake at the Ballenas Transform, Gulf of California. The model results suggest that the Ballenas Transform accommodates basically the entire Baja California-North America plate relative motion, with a slip rate of $47.3 \pm 0.8 \mathrm{~mm} / \mathrm{yr}$, far exceeding the rate of individual intracontinental strike-slip faults in the north, i.e., the San Andreas Fault. Our interseismic and coseismic deformation modeling have provided information on the interseismic locking depth $(11.4 \pm 1.1 \mathrm{~km})$ and geodetic fault rupture width and depth $(14 \mathrm{~km})$. We explain the different depth estimates by postseismic deformation, as later measurements from GPS show evidence for postseismic relaxation. Associated relaxation time estimates are consistent with but do not prove rheological contrast across the plate boundary.

\section{References}

Allmann, B. P., and P. M. Shearer (2009), Global variations of stress drop for moderate to large earthquakes, J. Geophys. Res., 114, B01310, doi:10.1029/2008JB005821.

Aragon-Arreola, M., and A. Martin-Barajas (2007), Westward migration of extension in the northern Gulf of California, Mexico, Geology, 35(6), 571-574, doi:10.1130/G23360A.1. 
Argus, D. F., and R. G. Gordon (2001), Present tectonic motion across the Coast Ranges and San Andreas fault system in central California, Geol. Soc. Am. Bull., 113(12), 1580-1592, doi:10.1130/0016-7606(2001)113<1580:PTMATC >2.0.CO;2.

Atwater, T., and J. Stock (1988), Pacific-North America plate tectonics of the Neogene southwestern United States: An update, in Integrated Earth and Environmental Evolution of the Southwestern United States: The Clarence A. Hall, Jr., edited by W. G. Ernst and C. A. Nelson, pp. 393-420, Bellwether, Columbia.

Atwater, T., and J. M. Stock (1998), Pacific-North America plate tectonics of the Neogene southwestern United States: An update, Int. Geol. Rev., 40(5), 375-402, doi:10.1080/00206819809465216.

Bennett, S. E. K., M. E. Oskin, and A. Iriondo (2013), Transtensional rifting in the Proto-Gulf of California, near Bahia Kino, Sonora, Mexico, Geol. Soc. Am. Bull., 125(11/12), 1752-1782, doi:10.1130/B30676.1.

Castro, R. R., A. Perez-Vertti, I. Mendez, A. Mendoza, and L. Inzunza (2010), Location of moderate-sized earthquakes recorded by the NARS-Baja Array in the Gulf of California region between 2002 and 2006, Pure Appl. Geophys., doi:10.1007/s00024-010-0177-y.

Castro, R. R., C. Valdes-Gonzalez, P. Shearer, V. Wong, L. Astiz, F. Vernon, A. Perez-Vertti, and A. Mendoza (2011), The 3 August $M_{w} 6.9$ Canal de Ballenas Region, Gulf of California, earthquake and its aftershocks, Bull. Seismol. Soc. Am., 101(3), 929-939, doi:10.1785/0120100154.

Cervelli, P., M. H. Murray, P. Segall, Y. Aoki, and T. Kato (2001), Estimating source parameters from deformation data, with an application to the March 1997 earthquake swarm off the Izu Peninsula, Japan, J. Geophys. Res., 106(B6), 11,217-11,237, doi:10.1029/2000JB900399.

Chen, C. W., and H. A. Zebker (2001), Two-dimensional phase unwrapping with use of statistical models for cost functions in nonlinear optimization, J. Opt. Soc. Am., 18(2), 338-351, doi:10.1364/JOSAA.18.000338.

DeMets, C., and T. H. Dixon (1999), New kinematic models for Pacific-North America motion from 3 Ma to present, I: Evidence for steady motion and biases in the NUVEL-1A model, Geophys. Res. Lett., 26, 1921-1924, doi:10.1029/1999GL900405.

DeMets, C., R. G. Gordon, D. F. Argus, and S. Stein (1990), Current plate motions, Geophys. J. Int., 101, 425-478, doi:10.1111/j.1365-246X.1990.tb06579.x.

DeMets, C., R. G. Gordon, D. F. Argus, and S. Stein (1994), Effect of recent revisions to the geomagnetic reversal time-scale on estimates of current plate motions, Geophys. Res. Lett., 21, 2191-2194, doi:10.1029/94GL02118.

DeMets, C., R. G. Gordon, and D. F. Argus (2010), Geologically current plate motions, Geophys. J. Int., 181(1), 1-80, doi:10.1111/ j.1365-246X.2009.04491.x.

Dixon, T. H., G. Gonzalez, S. M. Lichten, D. M. Tralli, G. Ness, and P. Dauphin (1991), A preliminary determination of Pacific-North America relative motion in the southern Gulf of California using the Global Positioning System, Geophys. Res. Lett., 18, 861-864, doi:10.1029/ 91GL01062.

Dixon, T. H., S. Robaudo, J. Lee, and M. C. Reheis (1995), Constraints on present day basin and range deformation from Space Geodesy, Tectonics, 14, 755-772, doi:10.1029/95TC00931.

Dixon, T. H., F. Farina, C. DeMets, F. Suarez-Vidal, J. Fletcher, B. Marquez-Azua, M. Miller, O. Sanchez, and P. Umhoefer (2000a), New kinematic models for Pacific-North America motion from 3 Ma to present, II: Evidence for a "Baja California shear zone", Geophys. Res. Lett., 27, 3961-3964, doi:10.1029/2000GL008529.

Dixon, T. H., M. Miller, F. Farina, H. Wang, and D. Johnson (2000b), Present-day motion of the Sierra Nevada block and some tectonic implications for the Basin and Range Province, North America Cordillera, Tectonics, 19, 1-24, doi:10.1029/1998TC001088.

Dziewonski, A. M., T. A. Chou, and J. H. Woodhouse (1981), Determination of earthquake source parameters from waveform data for studies of global and regional seismicity, J. Geophys. Res., 86, 2825-2852, doi:10.1029/JB086iB04p02825.

Ekström, G., M. Nettles, and A. M. Dziewonski (2012), The Global CMT Project 2004-2010: Centroid-moment tensors for 13,017 earthquakes, Phys. Earth Planet. Inter., 200-201, 1-9, doi:10.1016/j.pepi.2012.04.002.

Escalona-Alcazar, F. J., and L. A. Delgado-Argote (2000), Estudio de la deformaction en las Islas San Lorenzo y las Animas, Golfo de California: Implicaciones sobre su desplazamiento como bloquo rigido desde el Plioceno Tardio, GEOS, 20, 8-20.

Farr, T. G., and M. Kobrick (2000), Shuttle Radar Topography Mission produces a wealth of data, Trans., AGU, 81, 583-585.

Fattahi, H., and F. Amelung (2014), InSAR uncertainty due to orbital errors, Geophys. J. Int., 199(1), 549-560, doi:10.1093/gji/ggu276.

Faulds, J. E., C. D. Henry, and N. H. Hinz (2005a), Kinematics of the northern Walker Lane: An incipient transform fault along the Pacific-North American plate boundary, Geology, 33(6), 505-508.

Faulds, J. E., C. D. Henry, N. H. Hinz, P. S. Drakos, and B. Delwiche (2005b), Transect across the Northern Walker Lane, northwest Nevada and northeast California: An incipient transform fault along the Pacific-North America plate boundary, in Interior Western United States, vol. 6, edited by J. Pederson and C. M. Dehler, pp. 129-150, Geol. Soc. Am. Field Guide, doi:10.1130/2005.fld006(06).

Francheteau, J., and X. Le Pichon (1972), Marginal fracture zones as structural framework of continental margins in South Atlanic Ocean, Am. Assoc. Pet. Geol. Bull., 56, 991-1007.

Gastil, R. G., and D. Krummenacher (1977), Reconnaissance geology of coastal Sonora between Puerto Lobos and Bahia Kino, Geol. Soc. Am. Bull., 88(2), 189-198, doi:10.1130/0016-7606(1977.

Gastil, R. G., R. P. Phillips, and E. C. Allison (1975), Reconnaissance geology of the State of Baja, California, Mem. Geol. Soc. Am., 140, 170-170.

Goff, J. A., E. A. Bergman, and S. C. Solomon (1987), Earthquake source mechanism and transform fault tectonics in the Gulf of California, J. Geophys. Res., 92, 10,485-10,510, doi:10.1029/JB092iB10p10485.

González-Fernández, A., J. J. Dañobeitia, L. A. Delgado-Argote, F. Michaud, D. Córdoba, and R. Bartolomé (2005), Mode of extension and rifting history of upper Tiburón and upper Delfín basins, northern Gulf of California, J. Geophys. Res., 110, B01313, doi:10.1029/2003JB002941.

Hackl, M., R. Malservisi, U. Ugentobler, and R. Wonnacott (2011), Estimation of velocity uncertainties from GPS time series: Examples from the analysis of the South African Trignet network, J. Geophys. Res., 116(B11), B11404, doi:10.1029/2010JB008142.

Hackl, M., R. Malservisi, U. Hugentobler, and Y. Jiang (2013), Velocity covariance in the presence of anisotropic time correlated noise and transient events in GPS time series, J. Geodyn., 72, 36-45, doi:10.1016/j.jog.2013.08.007.

Hjörleifsdottir, V., and G. Ekström (2010), Effects of three-dimensional Earth structure on CMT earthquake parameters, Phys. Earth Planet. Inter., 179, 178-190, doi:10.1016/j.pepi.2009.11.003.

Jonsson, S., H. Zebker, P. Segall, and F. Amelung (2002), Fault slip distribution of the $1999 M_{w} 7.1$ Hector Mine, California, Earthquake, estimated from Satellite Radar and GPS Measurements, Bull. Seismol. Soc. Am., 92(4), 1377-1389, doi:10.1785/0120000922.

King, G. C. P., R. S. Stein, and J. Lin (1994), Static stress changes and the triggering of earthquakes, Bull. Seismol. Soc. Am., 84, 935-953.

Lay, T., and T. C. Wallace (1995), Modern Global Seismology, pp. 1-517, Academic Press, San Diego.

Li, Q., and M. Liu (2006), Geometrical impact of the San Andreas Fault on stress and seismicity in California, Geophys. Res. Lett., 33, L08302, doi:10.1029/2005GL025661.

Lizarralde, D., et al. (2007), Variation in styles of rifting in the Gulf of California, Nature, 448, 466-469, doi:10.1038/nature06035.

Lonsdale, P. L. (1985), A transform continental margin rich in hydrocarbons, Gulf of California, Am. Assoc. Pet. Geol. Bull., 69, 1160-1180.

Lonsdale, P. L. (1989), Geology and Tectonics History of the Gulf of California, In: The Geology of North America: The Eastern Pacific Ocean and Hawaii, Geol. Soc. Am. 
Lonsdale, P. L., and J. Kluesner (2010), Routing of terrigenous clastics to oceanic basins in the southern Gulf of California, Abstract T33C-2265 presented at 2010 Fall Meeting, AGU, San Francisco, Calif., 13-17 Dec.

Lopez-Pineda, L., C. J. Rebollar, and L. Quintanar (2007), Crustal thickness estimates for Baja California, Sonora, and Sinaloa, Mexico, using disperse surface waves, J. Geophys. Res., 112, B04308, doi:10.1029/2005JB003899.

Lopez-Pineda, L., L. Quintanar, C. I. Lopez, and H. E. Lozoya (2014), Active segment of the 12 November $2003 M_{w} 5.6$ earthquake at Salsipuedes oceanic basin, Gulf of California, Mexico, Geofis. Int., 53-1, 17-26.

Malservisi, R., et al. (2015), Multiscale postseismic behavior on a megathrust: The 2012 Nicoya earthquake, Costa Rica, Geochem. Geophys. Geosyst., doi:10.1002/2015GC005794.

Mao, A., G. A. Harrison, and T. H. Dixon, (1999), Noise in GPS coordinate time series, J. Geophys. Res., 104, 2797-2816.

Martin-Barajas, A., M. Gonzalez-Escobar, J. M. Fletcher, M. Pacheco, M. Oskin, and R. Dorsey (2013), Thick deltaic sedimentation and detachment faulting delay the onset of continental rupture in the Northern Gulf of California: Analysis of seismic reflection profiles, Tectonics, 32, 1294-1311, doi:10.1002/tect.20063.

McCrory, P. A., D. S. Wilson, and R. G. Stanley (2009), Continuing evolution of the Pacific-Juan de Fuca-North America slab window system: A trench-ridge-transform example from the Pacific Rim, Tectonophysics, 464, 30-42, doi:10.1016/j.tecto.2008.01.018.

McQuarrie, N., and B. P. Wernicke (2005), An animated tectonic reconstruction of southwestern North America since $36 \mathrm{Ma}$, Geosphere, 1, $147-172$.

Minster, J. B., and T. H. Jordan (1978), Present-day plate motions, J. Geophys. Res., 83(B11), 5331-5354, doi:10.1029/JB083iB11p05331.

Munguia, L., M. Reichle, A. Reyes, R. Simons, and J. Brune (1977), Aftershocks of the 8 July, 1975 Canal de Las Ballenas, Gulf of California, earthquake, Geophys. Res. Lett., 4, 507-509, doi:10.1029/GL004i011p00507.

Okada, Y. (1985), Surface deformation due to shear and tensile faults in a half-space, Bull. Seismol. Soc. Am., 75(4), 1135-1154.

Plattner, C., R. Malservisi, T. H. Dixon, P. LaFemina, G. F. Sella, J. Fletcher, and F. Suarez-Vidal (2007), New constraints on relative motion between the Pacific Plate and Baja California microplate (Mexico) from GPS measurements, Geophys. J. Int., 170, 1373-1380, doi:10.1111/ j.1365-246X.2007.03494.x.

Plattner, C., R. Malservisi, and R. Govers (2009), On the plate boundary forces that drive and resist Baja California motion, Geology, 37(4), 359-362, doi:10.1130/G25360A.

Plattner, C., R. Malservisi, K. P. Furlong, and R. Govers (2010), Development of the Eastern California Shear Zone-Walker Lane belt: The effects of microplate motion and pre-existing weakness in the Basin and Range, Tectonophysics, 485, 78-84, doi:10.1016/j.tecto.2009.11.021.

Plattner, C., F. Amelung, S. Baker, R. Govers, and M. Poland (2013), The role of viscous spreading of the deep magma reservoir for volcanic flank motion at Kilauea Volcano, Hawai'i, J. Geophys. Res. Solid Earth, 118, 1-14, doi:10.1002/jgrb.50194.

Rebischung, P., J. Griffiths, J. Ray, R. Schmid, X. Colilieux, and B. Garayt (2012), IGS08: The IGS realization of the ITRF2008, GPS Solut., 16, 483-494, doi:10.1007/s10291-011-0248-2.

Rebollar, C. J., L. Quintanar, R. R. Castro, S. M. Day, J. Madrid, J. N. Brune, L. Astiz, and F. Vernon (2001), Source characteristics of a 5.5 magnitude earthquake that occurred in the transform fault system of the Delfin Basin in the Gulf of California, Bull. Seismol. Soc. Am., 91(4), 781-791, doi:10.1785/0120000077.

Reichle, M., and I. Reid (1977), Detailed study of earthquake swarms from the Gulf of California, Bull. Seismol. Soc. Am., 67, 159-171.

Rodriguez-Lozoya, H. E., L. Quintanar, R. Ortega, C. J. Rebollar, and Y. Yagi (2008), Rupture process of four medium-sized earthquakes that occurred in the Gulf of California, J. Geophys. Res., 113, B10301, doi:10.1029/2007JB005323.

Rosen, P. A., S. Hensley, G. Peltzer, and M. Simons (2004), Update repeat orbit interferometry package released, Trans., AGU, 85, 47.

Savage, J. C., and R. O. Burford (1973), Geodetic determination of relative motion in central California, J. Geophys. Res., 78(5), 832-845, doi:10.1029/JB078i005p00832.

Schmalzle, G., T. H. Dixon, R. Malservisi, and R. Govers (2006), Strain accumulation across the Carrizo Segment of the San Andreas Fault, California: Impact of laterally varying crustal properties, J. Geophys. Res., 111, B05403, doi:10.1029/2005JB003843.

Segall, P. (2010), Earthquake and Volcano Deformation, Princeton Univ. Press, Princeton, N. J.

Stock, J., A. Martin-Barajas, M. Martinez-Lopez, and A. Chapman (2008), Net slip across the Ballenas transform fault measured from offset ignimbrite deposits. Abstract T11A-1853 presented at 2008 Fall Meeting, AGU, San Francisco, Calif., 15-19 Dec.

Sumy, D. F., J. B. Gaherty, W.-Y. Kim, T. Diehl, and J. A. Collins (2013), The mechanisms of earthquakes and faulting in the southern Gulf of California, Bull. Seismol. Soc. Am., 103(1), 487-506, doi:10.1785/0120120080.

Toda, S., R. S. Stein, V. Sevilgen, and J. Lin (2011), Coulomb 3.3 graphic rich deformation and stress change software for earthquake, tectonic, and volcano research and teaching-user guide, U.S. Geol. Surv. Open File Report 2011-1060, 63 p.

Vacquier, V., and R. E. Whiteman (1973), Measurement of fault displacement by optical parallax, J. Geophys. Res., 78, 851-857, doi:10.1029/ JB078i005p00851.

Wang, Y., D. W. Forsyth, and B. Savage (2009), Convective upwelling in the mantle beneath the Gulf of California, Nature, 26, 499-501, doi:10.1038/nature08552.

Zumberge, J. F., M. B. Heflin, D. J. Jefferson, M. M. Watkins, and F. H. Webb (1997), Precise point positioning for the efficient and robust analysis of GPS data from large networks, J. Geophys. Res., 102(3), 5005-5017, doi:10.1029/96JB03860. 